\title{
Fringes of the empire: diet and cultural change at the Roman to post-Roman transition in NW Iberia
}

Article

Accepted Version

López-Costas, O. and Muldner, G. (2016) Fringes of the empire: diet and cultural change at the Roman to post-Roman transition in NW Iberia. American Journal of Physical Anthropology. ISSN 1096-8644 doi: https://doi.org/10.1002/ajpa.23016 Available at https://centaur.reading.ac.uk/66226/

It is advisable to refer to the publisher's version if you intend to cite from the work. See Guidance on citing.

To link to this article DOI: http://dx.doi.org/10.1002/ajpa.23016

Publisher: Wiley

All outputs in CentAUR are protected by Intellectual Property Rights law, including copyright law. Copyright and IPR is retained by the creators or other copyright holders. Terms and conditions for use of this material are defined in the End User Agreement.

www.reading.ac.uk/centaur 
Central Archive at the University of Reading

Reading's research outputs online 


\section{Fringes of the Empire: Diet and cultural change at the Roman to post-Roman Transition in NW Iberia}

\begin{tabular}{|r|l|}
\hline Journal: & American Journal of Physical Anthropology \\
\hline Manuscript ID & AJPA-2015-00393.R2 \\
\hline Wiley - Manuscript type: & Research Article \\
\hline Complete List of Authors: & $\begin{array}{l}\text { López-Costas, Olalla; Universidade de Santiago de Compostela, Group } \\
\text { Earth System Sciences, Departamento de Xeografía-Facultade de Xeografía } \\
\text { e Historia; Stockholm University, Archaeological Research Laboratory. } \\
\text { Department of Archaeology and Classical Studies, Wallenberglaboratoriet; } \\
\text { Universidad de Granada, Laboratory of Anthropology, Department of Legal } \\
\text { Medicine, Toxicology and Physical Anthropology, Faculty of Medicine } \\
\text { Müldner, Gundula; University of Reading, Department of Archaeology }\end{array}$ \\
\hline Key Words: & millet, saltmarsh influence, Migration period, stable isotopes, paleodiet \\
\hline $\begin{array}{r}\text { Subfield: Please select your } \\
\text { first choice in the first field.: }\end{array}$ & $\begin{array}{l}\text { Bioarchaeology [including forensics], Human biology [living humans; } \\
\text { behavior, ecology, physiology, anatomy] }\end{array}$ \\
\hline &
\end{tabular}




\section{Fringes of the Empire: Diet and cultural change at the Roman to post-Roman}

\section{Transition in NW Iberia}

$4{ }^{1}$ Group Earth System Sciences, Departamento de Xeografía, Facultade de Xeografía e Historia, 5 Universidade de Santiago de Compostela, Santiago de Compostela, 15782, Spain.

$6{ }^{2}$ Archaeological Research Laboratory, Stockholm University, Wallenberglaboratoriet, SE-10691 7 Stockholm, Sweden.

$8{ }^{3}$ Laboratory of Anthropology, Department of Legal Medicine, Toxicology and Physical Anthropology,

9 Faculty of Medicine, University of Granada, Granada 18012, Spain

$10{ }^{4}$ Department of Archaeology, University of Reading, Whiteknights, PO Box 227, Reading, RG6 6AB, 11 UK

13 Number of text pages: 26

14 Number of figures: 7

15 Number of tables: 7

16 Abbreviated title: Isotopic diet study in Roman and post-Roman A Lanzada

17 Key words (3-5): millet; saltmarsh influence; Migration period; stable isotopes;

18 paleodiet

$19 *$ corresponding author: Olalla López-Costas

20 Adress: Current adress: Stockholm University Arkeologiska forsknings laboratoriet 21 (AFL) SE-10691 Stockholm, Sweden.

22 Telephone number: +468164590

23 E.mail addresses: olallalc@gmail.com , olalla.lopez@usc.es , 24 olalla.lopez.costas@arklab.su.se

26 Grant sponsorship: OLC is funded by Plan Galego I2C mod.A (Xunta de Galicia). The 27 research was funded by projects “Antropoloxía dos restos óseos humanos de Galicia" 28 (Dirección Xeral de Patrimonio Histórico), GPC2014/009 and R2014/001 of Xunta de 29 Galicia. 
ABSTRACT (250)

\section{Objectives}

A growing number of paleodiet investigations over recent years have begun to reveal the stark subsistence strategies after its fall. The present study explores the dietary changes at the Roman to postof the changes that occurred at end of the Roman Empire in different regions across Europe and to also consider the influence of climate had on them.

\section{Materials and Methods}

We present the carbon and nitrogen stable isotope investigation in bone collagen from A Lanzada, NW Spain (100-700 AD), which was an important commercial, coastal settlement. A human sample of 59 individuals, 6 of them subadults, is compared with 31 faunal specimens, which include a number of marine fish.

\section{Results}

\section{Discussion}




\section{Introduction}

57

58

59

60

61

62

63

64

The study of diet and foodways and their change over time offers important insights into human societies and individuals in terms of their social and economic structure, health status and standards of living (Mintz and Du Bois 2002). Dietary change may be triggered by historical events, such as foreign invasions, but more often reflect general changes of the social, cultural, economic or environmental conditions humans lived in. Methodologies, such as the analysis of stable isotopes performed on human and faunal bone collagen, provide information on the major sources of protein intake (Jim et al. 2004) during the life of an individual (e.g. the review articles by Schwarcz and Schoeninger 1991; Sealy 2001) depending on the turnover of the analysed tissue (Hedges et al. 2007). These are a particularly efficient way of tracing the history of human diet and its changes over time. Recently, routine applications of this type of analysis have provided abundant data about the diet and subsistence strategies of ancient populations (e.g. in Spain Alexander et al. 2015; Arias and Schulting 2010; Davis 2002; Fuller et al. 2010; García-Guixé et al. 2009; García et al. 2004; García Guixé et al. 2006; López-Costas et al. 2015; Mundee 2009; Salazar-García et al. 2014; Van Strydonck et al. 2002; Van Strydonck et al. 2005). Consequently, it has now become established as a key tool for understanding the relationship between humans and their cultural and natural environment in the past.

The end of the Roman Empire and the Migration Period ( $5^{\text {th }}$ to $8^{\text {th }}$ centuries AD) had a profound impact on the European landscape, laying the foundations for the political geography of many modern European countries (Musset 1975). The Migration period has been relatively unexplored in Spanish archaeology compared to other periods; however, the interest in it has increased more recently. This is probably due to the realization that the demise of the Roman Empire had far-reaching consequences for 
81 the way of life and standards of living of the local populations, due to the breakdown of

82 the old political and economic structure, the Germanic invasions and the accompanying

83 climatic downturn which occurred at the end of the Roman Warm Period (among others

84 Büntgen et al. 2011; Martínez-Cortizas et al. 1999; Mighall et al. 2006). Previous

85 paleodietary studies of the Roman to post-Roman transition in Central and South-

86 eastern Europe have detected an increase in the consumption of $\mathrm{C}_{4}$ plant products, most

87 probably millet, which may have been related to the arrival of ethnic groups with

88 different cuisines and traditions (Hakenbeck et al. 2010; Lightfoot et al. 2012).

89 The Iberian Peninsula is considered an essential region in the Imperial economy,

90 especially during Late Roman times (Kulikowski 2004). Despite being conquered

91 relatively late (end of the 1st century BC) (Syme 1934), the Roman province of

92 Gallaecia, to the Northwest, played an essential role in the Atlantic trade routes and in

93 mining, among others. The historical importance of Northwest Iberia extended beyond

94 the end of the Roman Empire to the Migration period, also known as the "Germanic

95 invasions' in Spain. One of the main reasons is that the Iberian Peninsula, and the

96 Northwest in particular, was one of the first areas where the foreign populations

97 permanently settled (Kulikowski 2004; Musset 1975). The historical relevance of the

98 area contrasts with the poor knowledge of features related to everyday life, such as diet.

99 The historiography and archaeological evidence about these topics is scarce for Roman

100 times and dramatically decreases with the arrival of Germanic peoples (Díaz 2011).

101 In Gallaecia the overthrown of Roman rule by a Germanic group known as the

102 Sueves in the early $5^{\text {th }}$ century AD, is regarded as the end of the Roman period and the 103 beginning of Early Middle Ages (see Castellanos and Viso 2005; Díaz 2011 ). The

104 Sueves permanently settled in the area of modern day Galicia and North Portugal, 105 creating a Kingdom that lasted almost two centuries (AD 409-585). Recent 
106 palaeoenvironmental studies suggest that the landscape underwent a number of

107 significant human-made transformations during this time, through deforestation and 108 new modes of agriculture and animal husbandry, which still shape much of the 109 environment today (Ferro-Vázquez et al. 2014; Martínez Cortizas et al. 2005). These

110 changes could have implications for the subsistence economy during the transition from

111 Roman to post-Roman times, which may have left an imprint in human remains.

112 The present study explores the dietary changes at the Roman to post-Roman

113 transition in the Northwest Iberian Peninsula, in order to improve our understanding of

114 the end of the Roman Empire at the western fringe of Europe, paying particular 115 attention to the possible influence of climate. In order to address this aim, we carried out 116 a programme of carbon and nitrogen stable isotope analyses of bone collagen on 117 samples from the coastal cemetery site of A Lanzada (Galicia, NW Iberia) (100-700

118 AD) (Blanco Freijeiro et al. 1967), where two funerary areas have been described: one 119 from the Roman $\left(2^{\text {nd }}\right.$ to $4^{\text {th }}$ centuries AD) and the other from the post-Roman $\left(5^{\text {th }}\right.$ to $7^{\text {th }}$ 120 centuries AD) times (López-Costas 2015).

\section{THE COASTAL NECROPOLIS OF A LANZADA}

The archaeological site of A Lanzada is located in the province of Pontevedra

123 (Galicia, NW Spain) on a small headland just south of the O Grove peninsula, between

124 the estuaries of Arousa and Pontevedra, two of the so-called Rias Baixas (see Fig. 1).

125 Since the area is surrounded by the sea, a range of different coastal ecosystems occur in

126 the immediate vicinity and the position of the site once offered excellent control over

127 the maritime traffic along the coast (see Fig. 1). The soils are not particularly well suited

128 for agriculture due to their sandy texture, low water retention and high input of sea-

129 spray, and they are subject to constant winds and soil erosion; however, further inland, 
130 the quality of the soils improves (López-Costas et al. 2016). Fish and seafood are

131 abundant in the area and good pasture for domestic animals is provided by the many

132 halophytic grasses and shrubs that can be found locally on saltmarshes (Valdés-Bermejo 133 and Silva Pando 1986).

134 Probably because of its strategic location, A Lanzada area has been occupied 135 since prehistoric times. Remains from a Bronze to Iron Age settlement, a Roman and 136 post-Roman cemetery with possible traces of a settlement, as well as a defensive tower 137 and a Romanesque church from the medieval period have been found (Fariña Busto and 138 Filgueira Valverde 1974) (see Fig. 2). Recent excavations have uncovered salting 139 facilities for seafood dating back to the Iron Age and historical sources suggest that a 140 nearby marshland was intensively exploited for salt production during the Late Roman 141 and Medieval periods (Rodríguez Martínez et al. 2011). A significant amount of 142 imported pottery and other foreign artefacts dating from the $5^{\text {th }}$ century $\mathrm{BC}$ to the $6^{\text {th }}$ 143 century $\mathrm{AD}$, attests to A Lanzada lasting importance in the long-distance trade network 144 even after the end of the Roman phase (González Ruibal 2004; Naveiro López 1991). 145 Additionally, a large midden deposit, which consisted mainly of faunal remains 146 presumably dated from Iron to Roman period, was found in the area (Rodríguez 147 Martínez et al. 2011).

148 The main evidence of occupation from the Roman and post-Roman period is a 149 cemetery located at the Eastern edge of the headland (Fig. 2), which was partially 150 excavated during several campaigns between 1949 and 1963 (Blanco Freijeiro et al. 151 1967; Filgueira Valverde and Blanco Freijeiro 1962) and from 1975 to 1977 (Fariña 152 Busto 1975). Although many areas were intensively investigated, the available 153 documentation is of varied quality and only part of the results from the graves were 154 formally published (Blanco Freijeiro et al. 1961; Blanco Freijeiro et al. 1967; Carro 
155 Otero et al. 1987; Filgueira Valverde and Blanco Freijeiro 1962). The preservation of

156 the human bones was good and the archaeologists also collected some faunal remains 157 from the graves.

158 The burials belong to two funerary areas with different dating based on 159 archaeological evidence and radiocarbon dates (Fig. 2) (López-Costas 2015), 160 (information about individual burials is summarised in Table 3). Of the 85 skeletons, 161 including several sub-adults, which have been recovered, 59 were selected for this 162 study, based on suitable skeletal preservation and avoiding non-adults under 12 years 163 old.

164 The first phase comprises the burials from the northern cemetery area (Fig.2), 165 which are dated to the Roman period ( $2^{\text {nd }}$ to $4^{\text {th }}$ centuries $\mathrm{AD}$ ). The bodies were 166 predominantly aligned south-north and three main types of tombs have been recorded: 167 (1) simple earth graves or simple trench burials (see Fig. 3.A), (2) earth grave 168 surrounded by stones, (3) Tegulae grave (cappuccina) and/or earth grave with an imbrex 169 (curved tile) under the head (see Fig. 3.A). A detailed description of the burial rites has 170 been published elsewhere (López-Costas 2015). About 50\% of the individuals were 171 accompanied by dress accessories (e.g. hob-nails), which suggests that they had been 172 buried clothed. Grave goods (pottery, glass) were also frequently present and at least 173 three skeletons were accompanied by coins, which dated between 213 and 325 AD. 174 While the majority of burials were inhumations, two cremation burials also belong to 175 this phase, but no human remains were collected from them. Following Toynbee's 176 (1971) classification, the burials could be interpreted as a lower-middle class Roman 177 cemetery. 
178 The second phase of the cemetery was excavated during the 1970 s. According to

179 the photographs it was located south of the previous excavations (Fig. 2) and it was

180 characterised by either simple earth graves or graves constructed from stone slabs (Fig.

181 3.B) (López-Costas 2015). Three of the stone slab coffins were used for multiple

182 consecutive burials (Fig. 3B). All skeletons were west-east oriented, laid in supine

183 position and there was a total absence of grave goods, although scallop shells found

184 near some of the bodies may have been deliberately placed. This second phase has been

185 dated to the post-Roman or Migration period, $5^{\text {th }}$ to $7^{\text {th }}$ centuries AD. Although stone

186 slab tombs have also been found in earlier Roman cemeteries in other parts of the

187 Empire (e.g.Philpott 1991), this mode of burial is known as typical for the Germanic

188 kingdoms of NW Iberia, where it has also been associated with Christian burials (Fariña

189 Busto and Suarez Otero 1997).

190

\section{MATERIAL AND METHODS}

Samples for isotope analysis were taken from a total of 59 humans and 31

192 animals. The faunal set comprised bone and tooth samples mainly of cattle (11),

193 sheep/goat (9) and pig (3) that were taken from the burials themselves, although they

194 may originally have belonged to the midden deposit from the Iron and Roman Age. We

195 also included seven marine animals, six bony fish and a dolphin, obtained from $15^{\text {th }}$

196 century contexts at the site of Ponte do Burgo at Pontevedra, ca. $20 \mathrm{~km}$ south-east of A

197 Lanzada (animal species information are summarized in Table 1), in order to trace the

198 isotopic background of the marine resources. The human sample was made up of 59

199 individuals: 38 from the first phase of the cemetery and 20 from the second, later phase,

200 as well as a single medieval $\left(10^{\text {th }}\right.$ century AD) skeleton found in the western part of the

201 site. The male/female ratio of the human sample was almost 1:1 (29/24 and 6

202 subadults). The remains of sub-adults (with an age-at-death over 12 years in order to 
203 avoid the breast-feeding effect; see for example Fuller et al. 2006) were included if they

204 were well preserved. Since the mode of excavation used from the 1950s-1970 implied 205 the incomplete retrieval of the skeletons and, specifically, the lack of smaller bones like 206 ribs, samples were taken from various skeletal elements (table 3). The human remains 207 were examined morphologically using standard methods for human osteological 208 analysis and reference database containing other Iberian populations. Detailed results of 209 osteological and paleopathological analysis are presented elsewhere (López-Costas 210 2012).

211 The isotopic analyses were carried out at the Department of Archaeology at the 212 University of Reading (U.K.). Bone collagen was extracted following the method 213 described by Longin (1971) with modifications recommended by Collins and Galley 214 (1998), according to the protocol described in Britton et al. (2008). No ultrafiltration 215 was applied (Pestle et al. 2014). The degree of preservation has been addressed by 216 Pyrolysis GC/MS, finding no relationship between the molecular and isotopic $\left(\delta^{13} \mathrm{C}\right.$ and $217 \delta^{15} \mathrm{~N}$ ) composition of extracted bone collagen (Kaal et al. 2016).

218 Carbon and nitrogen stable isotope ratios were measured in duplicate on a 219 Europa 20-20 isotope ratio mass spectrometer coupled to a Sercon elemental analyzer. 220 Analytical error was calculated by repeated analyses of internal standards and was $221 \pm 0.2 \%$ or less for both elements (1 s.d.- standard deviation). Statistical analysis of the 222 data was made using the program SPSS 16. The comparisons among two groups were 223 computed by Student's t-test (t-test), or Mann-Whitney U test (M-W-test) whenever the 224 size of one of the series was equal or smaller than 15 individuals. The non-parametric 225 Kruskal-Wallis (K-W test) test was performed for comparisons of more than two 226 series/groups, since at least one series had less than 15 individuals (e.g. comparisons 227 among three groups of animals or different age groups in humans). 
Even though the low $\mathrm{pH}$ of Galician soils commonly causes poor skeletal preservation (López-Costas 2012; López-Costas et al. 2016), the collagen obtained from

231 the A Lanzada samples was well preserved with an average yield of $8.3 \pm 5.1 \mathrm{wt} \%$

232 (1s.d.). The carbon $(35.7 \pm 6.8 \mathrm{wt} \% \mathrm{C})$ and nitrogen $(12.6 \pm 2.6 \mathrm{wt} \% \mathrm{~N})$ contents

233 indicate that the majority of the samples had good preservation. Samples with lower 234 contents have not atypical values in other parameters and all human and animal $\mathrm{C} / \mathrm{N}$ ratios 235 were between 3.1 and 3.6. The individual data and summary statistics are given in 236 Tables 1-7. Data are plotted in Figures 4-6.

\section{Faunal isotope data}

Since this is the first stable isotope study on material from the North-West

239 Iberian coast, the analysis of animal remains is important in order to map the $\delta^{13} \mathrm{C}$ and $240 \delta^{15} \mathrm{~N}$ baseline variations in the A Lanzada environment. The terrestrial animals have a 241 relatively wide range of carbon and nitrogen isotope values of $-19.9 \pm 1.2 \%$ o $(-21.5$, $24216.4 \%$ ) and $7.8 \pm 1.8 \%$ (4.5, 11.7\%o), respectively (see Table 2 for basic summary 243 statistics). No systematic differences were found between herbivores and omnivores $244\left(\mathrm{M}-\mathrm{W}\right.$-test $\mathrm{U}=41.500 \mathrm{p}=0.40$ for $\delta^{13} \mathrm{C} ; \mathrm{U}=48.000, \mathrm{p}=0.17$ for $\left.\delta^{15} \mathrm{~N}\right)$, or between the three 245 most common animal groups, cattle, sheep-goat and pigs $\left(\delta^{13} \mathrm{C}:\right.$ Kruskal=Wallis test $246 \mathrm{H}_{(2)}=2.85, \mathrm{p}=0.240 ; \delta^{15} \mathrm{~N}: \mathrm{K}-\mathrm{W}$ test $\left.\mathrm{H}_{(2)}=2.95, \mathrm{p}=0.229\right)$. The different groups of 247 animals are discussed below.

Herbivores. The $\delta^{13} \mathrm{C}$ of the terrestrial herbivores range over almost 3\% ($24921.5 \%$ to- $18.8 \%$; $-20.2 \pm 0.7 \%$, average \pm standard deviation), excluding the outlier $250906 \mathrm{a}$ (see below). These values are similar to those observed at the Balearic sites (Fuller 251 et al. 2010; García et al. 2004) and indicate a diet based on $\mathrm{C}_{3}$-plants. High carbon 
252 isotope values in some of the animals (with $\delta^{13} \mathrm{C}>\sim-20 \%$ ) are consistent with the 253 presence of small amounts of $\mathrm{C}_{4}$ plants or seaweed, in the food chain, or alternatively 254 with grazing on saline pastures (see discussion below). Consumption of such resources 255 is particularly evident in the case of outlier 906a (Fig. 4). The sample belonged to a 256 young sheep or goat (less than 24 months) with elevated $\delta^{13} \mathrm{C}\left(-17.7 \%\right.$ ) and $\delta^{15} \mathrm{~N}$ 257 (11.2\%). According to the age at death, part of the enrichment could be related to the 258 suckling effect (Balasse and Tresset 2002), but the inputof $\mathrm{a}^{13} \mathrm{C}$-enriched supplement 259 fodder is also likely. The fact that this signal is particularly evident in a young animal 260 could suggest that it was a seasonal rather than year-round supplement to herbivore diet 261 at A Lanzada. Dental serial sections would be needed to test this hypothesis (see for 262 example Balasse et al. 2006).

263 The herbivore $\delta^{15} \mathrm{~N}$ also shows a wide range of variation, over 5.5\%, and a mean 264 of $7.4 \pm 1.6 \%$. In this context, it is remarkable that about half the samples have $\delta^{15} \mathrm{~N}$ 265 between $8 \%$ and $10 \%$ which are elevated values in comparison with most other sites 266 from West and South-West Europe (e.g.. Craig et al. 2009; Fuller et al. 2010; García267 Guixé et al. 2009; García et al. 2004; Müldner and Richards 2007; Stevens et al. 2010) 268 (see Fig. 4).

While a number of factors can lead to ${ }^{15} \mathrm{~N}$-enriched values in plants and 270 herbivore tissues, such an effect has been specifically observed for saline soils including 271 animals grazing in salt-marshes (Britton et al. 2008; Cloern et al. 2002; Heaton 1987; 272 Van Groenigen and Van Kessel 2002; Virginia and Delwiche 1982). It is therefore 273 reasonable to assume that the high herbivore $\delta^{15} \mathrm{~N}$ can be attributed to the environmental 274 conditions at A Lanzada. It is possible that traditional farming practices, which are 275 documented for the area in recent historical times and involve the fertilization of fields 276 with seaweed, seagrass or small crustaceans, were already in use in the more distant past 
277 (Ferreiro García et al. 1993; Pérez García 1979; Villares et al. 2007), affecting the 278 nitrogen isotope composition of the crops (see Fraser et al. 2011). While direct evidence 279 for this is lacking for the Roman period, soil characteristics (i.e. acidic pH) could 280 suggest that these methods of fertilization may already have been practiced in antiquity.

281 Nevertheless, it is also likely that humans exploited the nearby O'Vao salt-marshes as 282 pasture grounds for at least part of the year. Salt-marsh grazing could also explain the $283{ }^{13} \mathrm{C}$-enrichment in the bone collagen of several of the animals, either through the effect 284 of salinity on the carbon isotope composition of $\mathrm{C}_{3}$-plants (e.g. van Groenigen and van 285 Kessel 2002) or through direct input of $\mathrm{C}_{4}$-plants to the herbivore diet: one of the 286 common halophytes, or salt-loving plants, in the marshland near A Lanzada today is 287 Spartina maritima (Valdés-Bermejo and Silva Pando 1986), which follows the $\mathrm{C}_{4}$ 288 photosynthetic pathway (Sage and Monson 1999:221). Nevertheless, since millet, also a $289 \mathrm{C}_{4}$-plant which is known to have been used for animal foddering in classical times (see 290 Spurr 1986), was cultivated in Roman Galicia (Dopazo Martínez et al. 1996), it also 291 may be responsible for the elevated $\delta^{13} \mathrm{C}$ in the herbivores, as is the use of sea-weed as 292 supplementary fodder, for example during the winter months (see Balasse et al. 2006).

293 In summary, even though the method employed here does not allow us to 294 distinguish between the possible mechanisms and pathways that could explain the 295 herbivore isotope data, it appears that the coastal location and ecology of A Lanzada 296 had a significant impact on the isotopic composition of the foods available to animals 297 (and, by implication, humans) at the site, which will need to be taken into account when 298 interpreting the human data. Since it is likely that high herbivore $\delta^{15} \mathrm{~N}$ can be attributed 299 to the specific conditions at the coast, it can further be hypothesed that animals with 300 lower nitrogen isotope values $(<\sim 6 \%)$ were therefore not raised at A Lanzada but 
301 brought there from further inland, demonstrating the wider connections of the site in 302 antiquity.

Omnivores. Although only three pigs were available for sampling, their results

304 are surprisingly varied, ranging from $-21.2 \%$ to $-16.4 \%$ for carbon and from $8.0 \%$ to

$30511.7 \%$ o for nitrogen isotope values. This indicates very different diets or management

306 strategies, from exclusively $\mathrm{C}_{3}$-terrestrial foods to a significant input of $\mathrm{C}_{4}$-plants or,

307 perhaps more likely, giving the scavenging behaviour of pigs and the fact that fish-

308 waste must almost certainly have been freely accessible on site, marine-based protein.

309 Sample $906 \mathrm{~b}$ (Fig. 4), the pig with the highest $\delta^{13} \mathrm{C}$ is, again a young animal (less than

31012 months) and its $\delta^{15} \mathrm{~N}$ is therefore likely elevated by the suckling effect.

311 Marine Animals. The fish bones were tentatively identified as belonging to six

312 different individuals of four species, (see Table 1). Even though the remains are not

313 from A Lanzada itself but from a site nearby, all fish, as well as one marine mammal

314 (dolphin), are native to the Galician coast and have evidently been frequently consumed

315 by past humans (the sampled dolphin vertebra also bore butchery marks). Therefore

316 they should provide suitable reference values for the local marine ecosystem.

317 The $\delta^{13} \mathrm{C}$ average of the marine animals is $-12.0 \pm 0.6 \%$ (see Table 2), which is 318 comparable to data from the Atlantic coast (Barrett et al. 2008). While the carbon 319 isotope range is relatively narrow (1.5\%), the $\delta^{15} \mathrm{~N}$ values spread over 5.9\%o, 320 presumably reflecting differences in fish ecology, trophic level and size (Tables 1-2).

\section{Human diet at A Lanzada}

The isotopic data from the human bone collagen are remarkably variable.

323 Human samples have a $\delta^{13} \mathrm{C}$ range of $5.9 \%$ (-18.7 to $-12.8 \%$ ) with a mean of -

$32416.0 \pm 1.5 \%$ ( 1 s.d.); as well as $\delta^{15} \mathrm{~N}$ range of $3.9 \% 0(10.5 \%$ to $14.4 \%$ ) with a moderately 
325 high average of $12.3 \pm 0.9 \%$ (1 s.d.) (Fig.5). The carbon isotope ratios from A Lanzada

326 are among the most ${ }^{13} \mathrm{C}$-enriched values observed in any Iberian population, including

327 Mesolithic hunter-gatherers (Fuller et al. 2010; García et al. 2004; García Guixé et al.

328 2006), but excluding other Galician coastal populations (López-Costas 2012). Although

329 some individuals from Islamic sites on Ibiza (Fuller et al. 2010) and Valencia

330 (Alexander et al. 2015) exhibit similar $\delta^{13} \mathrm{C}$, the population averages are considerably

331 lower.

332 Even though the isotopic results suggest considerable heterogeneity in the

333 human diets at A Lanzada, no significant differences exist between males and females

334 (Student t-test $\delta^{13} \mathrm{C}: \mathrm{t}_{(51)}=-1.210 \mathrm{p}=0.23 ; \delta^{15} \mathrm{~N}: \mathrm{t}_{(51)}=-1.030 \mathrm{p}=0.308$ ) or different ages-

335 at-death (Kruskal-Wallis test $\delta^{13} \mathrm{C}: \quad \mathrm{H}_{(3)}=0.022 \mathrm{p}=0.99 ; \quad \delta^{15} \mathrm{~N}: \quad \mathrm{H}_{(3)}=5.119 \quad \mathrm{p}=0.16$ )

336 regardless of the time period.

337 Burial rite, however, and in particular tomb typology shows an association with

338 the isotopic data. It is worth to remind that tomb typology is a clear reflection of the two

339 time periods they represent, Roman and post-Roman (see methods and material

340 section). Kruskal-Wallis combined with Dunn-Bonferroni post-hoc tests indicate that

341 the $\delta^{13} \mathrm{C}$ of individuals buried in stone-slab graves are significantly different from those

342 in simple earth graves $(p=0.023)$, tegula graves $(p=0.001)$ and stone graves $(p=0.023$;

$343 \mathrm{~K}-\mathrm{W}$ test $\left.\mathrm{H}_{(3)}=16.65, \mathrm{p}=0.001\right)$. Differences in $\delta^{15} \mathrm{~N}$ are not significant $\left(\mathrm{H}_{(3)}=6.69\right.$,

$344 \mathrm{p}=0.082$ ). This trend is even stronger when burials from the different time-periods are

345 compared.

346 Bones of individuals in post-Roman burials (which include all stone-slab graves

347 and a number of simple earth graves) are significantly enriched in ${ }^{13} \mathrm{C}$ and ${ }^{15} \mathrm{~N}$ over

348 those of the Roman burials (which comprise stone graves, tegula graves as well as earth 
graves) (Roman vs. post-Roman $\mathrm{M}-\mathrm{W}$ test $\delta^{13} \mathrm{C}, \mathrm{U}=29,475, \mathrm{p}<0.000 ; \delta^{15} \mathrm{~N}, \mathrm{U}=9.905$,

$350 \mathrm{p}=0.002$ ). Rather than dietary variation between individuals afforded different burial

351 rites, the observed isotopic differences between grave types therefore likely indicate a

352 significant shift in diet between the Roman and the post-Roman period. There are no

353 significant differences between males and females or age-groups within each of the time

354 periods (see Tables 6-7 and Fig. 6). The unique medieval skeleton from A Lanzada, the

355245 , plots most closely with the Roman samples (Fig. 5) and while a single sample is

356 insufficient to characterise the diet of a whole period, this result at least suggests a

357 continuation of dietary traditions at the site at least in broad terms.

358 Similarly high carbon isotope ratios observed in all the human samples from A

359 Lanzada have been previously related to marine fish or shellfish consumption in other

360 archaeological sites from different parts of Europe (e.g. Müldner and Richards 2007;

361 Richards and Hedges 1999; Schoeninger et al. 1983). The fact that A Lanzada site is

362 surrounded by the sea and deeply related to it, a variety of fish and shell species

363 (Vázquez Varela and García Quintela 1998), as well as fish hooks and net sinkers

364 (Suárez Otero and Fariña Busto 1990) and a fish-salting factory (Rodríguez Martínez et

365 al. 2011) were identified at the site, attesting to the importance of marine resources in

366 the life of the inhabitants. The $\delta^{15} \mathrm{~N}$ average indicates the presence of moderately

367 important sources of animal protein coming from the sea or inland. Even considering

368 the difficulties in interpreting the $\Delta^{15} \mathrm{~N}$ between human diet and collagen $\left(\mathrm{O}^{\prime}\right.$ Connell et

369 al. 2012), the observed values are in agreement with a high-moderate presence of

370 marine food in diet. An alternative explanation of ${ }^{13} \mathrm{C}$ enrichment is the direct or

371 indirect (animals fed with them) ingestion of $\mathrm{C}_{4}$ plants, such as millet (e.g. Fuller et al.

372 2010; Reitsema et al. 2010; Tafuri et al. 2009). Since millet (Setaria italica and, more

373 commonly, Panicum miliaceum) was commonly cultivated at A Lanzada and 
374 neighbouring areas during medieval and post-medieval times (Armas Castro 1992;

375 Seijas Montero 2001) and in other areas of Galicia at least from the Iron Age onwards

376 (Aira Rodríguez et al. 1990; Dopazo Martínez et al. 1996; Ramil-Rego 1993), its

377 inclusion in peoples' diet could be as common as marine resources probably were. More

378 so, if we consider that the herbivores also show elevated ${ }^{13} \mathrm{C}$ values. In summary, the

379 observed $\delta^{13} \mathrm{C}$ and $\delta^{15} \mathrm{~N}$ data suggest that A Lanzada people may had have a diet with an

380 important input of marine resources and/or $\mathrm{C}_{4}$ plants, the exploitation of which is

381 supported by the historical and archaeological data available for the area.

382 In accordance with the previous discussion on the global human averages, the 383 differences observed between Roman and post-Roman individuals must have also been 384 caused by differential intake of $\mathrm{C}_{4} / \mathrm{C}_{3}$ plants and/or marine/terrestrial resources in a 385 mixed diet. Both, the $\delta^{13} \mathrm{C}$ and the $\delta^{15} \mathrm{~N}$, are significantly different between the two 386 groups, supporting the idea that post-Roman people may have consumed more marine 387 resources and $\mathrm{C}_{4}$ plants than the Roman individuals. However, the isotopic differences 388 between the averages (post-Roman $\bar{X}$-Roman $\bar{X}$ ) are wider for carbon $(2.4 \%$ ) than for 389 nitrogen $\left(0.7 \%\right.$ ), which suggests that $\mathrm{C}_{4}$ plants intake must have been more influential 390 in the intra-population differences. The linear trend between $\delta^{13} \mathrm{C}$ and $\delta^{15} \mathrm{~N}$ values 391 within the Roman sample shows a higher correlation $(r=0.49)$ than that for the post392 Roman one ( $\mathrm{r}=0.00$ ), which is totally flat (see fig. 7), a fact that also points in this 393 direction.

394 Unfortunately, there are no ichthyological and palaeobotanical studies on A 395 Lanzada for the periods studied by us, which prevents the comparison of the diachronic 396 trends in marine exploitation or millet cultivation from different methodological 397 perspectives. Similar analyses made on other Galician sites suggest that the 
398 establishment of Roman rule did not have marked effect on local Iron Age subsistence

399 strategies based on terrestrial animals (Dopazo Martínez et al. 1996). However, the

400 exploitation of marine resources seems to have had a progressive increase in NW Spain

401 from the $2^{\text {nd }}$ century $\mathrm{BC}$ onwards (although there is no data from post-Roman times)

402 (González Gómez de Agüero 2013). This enrichment parallels a seemingly marked

403 preference for more profitable species (e.g. sardine) and widespread access to marine

404 resources in coastal and inland regions from the $2^{\text {nd }}$ century AD onwards (Fuertes Prieto

405 and Fernández Rodríguez 2010; González Gómez de Agüero 2013). In fact, millets,

406 mainly Panicum miliaceum, continued to be very important crops in Northwest Iberia

407 throughout the Roman period (Tereso 2012). In contrast, almost nothing is known about

408 subsistence change after the demise of the Roman Empire in this area, mostly due to a

409 scarcity of well-excavated post-Roman settlements. Nevertheless, pollen evidence

410 shows a relatively sudden increase in deforestation in $5^{\text {th }}$ century AD (Martínez Cortizas

411 et al. 2005) which might suggest a change in agricultural preferences.

\section{Marine resources and millet vs. culture and environment}

413 Considering that the analytical data suggest an increase in the use of marine

414 resources and possibly also $\mathrm{C}_{4}$ plants (probably millet) by the A Lanzada population in

415 the post-Roman compared to the Roman period, we proceed to contextualize the

416 possible causes. Since it is well documented that both foods were readily available

417 during both periods (see discussion in the previous section), it is necessary to

418 understand the motivations that may have led to an increase in either resource in

419 everyday diet.

Millet has a short vegetative cycle and a wide germination temperature range

421 (16 $6^{\circ}$ to $\left.34^{\circ} \mathrm{C}\right)($ James et al. 2011), which allows it to adapt well to different soils and 
422 climates (Hunt and Jones 2008). That represented a clear advantage if a hard winter or

423 other event ruined crops with longer growing seasons. Similarly, fish and seafood were

424 abundant in A Lanzada coast and people could intensify their exploitation in case of 425 need.

426

Some important environmental changes also occurred across the Roman/post-

427 Roman transition. Modifications in marine currents from coastal areas near to A 428 Lanzada have been registered (Lebreiro et al. 2006; Muñoz Sobrino et al. 2014), which 429 may have led to an expansion of the salt-marshes and unpredictable changes in the 430 abundance of marine resources in estuaries. The climate was also affected (Martínez431 Cortizas et al. 1999; Mighall et al. 2006). The temperature and humidity conditions in 432 Galicia from the $2^{\text {nd }}$ to the $4^{\text {th }}$ century $\mathrm{AD}$ were not optimal for agriculture, but the 433 climate prevailing at this time would provide conditions necessary for a good growing 434 season for the majority of crops. In contrast, during post-Roman times there was a 435 considerable increase in humidity (pointing towards a two-fold increase in rainfall) 436 (Mighall et al. 2006) and temperatures fell in a similar way to those recorded in Central 437 Europe during the decline of the Roman Empire (Martínez-Cortizas et al. 1999). 438 Although rainfall seasonality has not been analyzed for this area, these latter weather 439 conditions could have been harmful for crops production especially for delicate cereals 440 such as wheat. The millets could have been used as a complement once other crops 441 failed, and even become a substantial part of human and animal diet. In this situation, 442 fish and shellfish could have also been used as alternative foods.

443 A probable increase in the consumption of millet between the Roman and post444 Roman periods has been reported for individuals from Central and Southeast European 445 populations, and has been convincingly explained by the post-Roman migrations 446 (Hakenbeck et al. 2010; Lightfoot et al. 2012). To our knowledge, there are no similar 
447 reports for Galicia or Iberia, a fact that may be explained by the absence of specific 448 paleodiet studies or ancient texts. The post-Roman burials of A Lanzada, and more 449 specifically the stone slabs tombs (where individuals with the highest isotopic values 450 were found), represent a burial rite frequently associated with the Suevic or Germanic 451 rule in Northwest Spain (Fariña Busto and Suarez Otero 1997). Since the Sueves arrived 452 in Galicia from Central Europe, where there is evidence for an increase in millet 453 consumption in the post-Roman period (Hakenbeck et al. 2010; Rösch 1998), they 454 could have brought with them a preference for this cereal. Unfortunately, little is known 455 about the Sueves' way of life and food preferences and it is difficult to assess their 456 impact on the local population. On the other hand, the burial rite observed at A Lanzada 457 in the post-Roman period, the WE-orientation and the absence of grave goods in 458 particular, has been also associated with Christian burials (Blanco Freijeiro et al. 1967). 459 Although Christianity played a less important role in rural areas compared to urban ones 460 (Kulikowski 2004), at least part of the post-Roman individuals might have lived as 461 Christians. The Early Christian Iberian doctrines taught abstinence from meat (Ferreiro 462 2008) and ancient texts promoted the idea of a largely vegetarian diet with occasional 463 supplements of fish: "the monks were encouraged to eat vegetables, greens, beans, and 464 on occasion fresh or salt fish" (Campos Ruíz and Roca Melia 1971). An increase in 465 fish consumption at A Lanzada might therefore be explained by their conversion to 466 Christianity. Nevertheless, these early food rules were largely directed at a monastic 467 (rather than lay) audience and economic status should therefore have had a greater 468 influence than religion on dietary preferences. economy of NW Iberian villages also took place. The Roman period $\left(1^{\text {st }}\right.$ century AD onwards) saw a high level of economic activity and coastal villages such as A Lanzada 
472 were thriving trading settlements on a maritime route that connected the Mediterranean 473 with the North Sea (Naveiro López 1991). From the $4^{\text {th }}$ century AD onwards, the 474 Roman Empire faced an economic crisis on the Iberian Peninsula which ultimately led 475 to its political break down (Kulikowski 2004) and resulted in a stark deterioration of the 476 Atlantic commerce (for NW Spain see Naveiro López 1991). The situation became 477 worse with the Germanic invasions and coastal settlements such as A Lanzada faced 478 isolation and political insecurity. The establishment of the Suevic Kingdom also appears 479 to have coincided with some dramatic environmental changes most likely resulting from 480 intensive economic activities, such as increasing deforestation, soil erosion, 481 metallurgical activity and pollution (Kylander et al. 2005; Martínez Cortizas et al. 2005; 482 Ramil-Rego et al. 1998). These factors could have caused a modification to the daily 483 subsistence strategies of the inhabitants of A Lanzada, such as in the way they exploited 484 their local resources, i.e. eating more fish if it was impossible to sell it.

485 In summary, the environmental and historical events that took place during the 486 occupation of the site provide observed number of plausible explanations to the 487 observed changes in human diet. Nevertheless, and especially since the factors are all 488 interrelated, it is difficult to distinguish whether these changes were primarily a 489 response to local or conditions or to the events that affected the Iberian Peninsula as a 490 whole at the time.

\section{CONCLUSIONS}

The analysis of this Roman and post-Roman community located on the very 494 fringes of Europe has revealed a very distinct food-web, which was highly dependent on 495 the surrounding marine environment. The connection with the sea and its resources was 
496 presumably working in many ways. The results suggest that animals were managed

497 using different strategies, which includes possible grazing on saline pasture or the use of 498 seaweed foddering. A variable amount of $\mathrm{C}_{4}$ plants, such as millet but also the 499 halophyte Spartina sp., would also have been present in the diet of herbivores. 500 Humans'diet may have been also closely connected to marine resources along the time 501 increasing the consumed amount during specific periods (e.g. post-Roman time). The 502 observed strong relationship with the sea emphasizes the importance of considering a 503 local perspective to understand dietary preferences, even in the well-defined and known 504 Roman period. Our study also suggests that the end of the Roman Empire and the Migration 506 Period had a profound impact on diet, as it presumably had in the European landscape. 507 Other authors' conclusions (Hakenbeck et al. 2010; Lightfoot et al. 2012) about the 508 increase in millet consumption during the post-Roman or the Early Medieval period 509 with respect to the Roman times are in agreement with our data. In the case of A 510 Lanzada, the rise of the use of millet may have been parallel to an increase in the 511 exploitation of local marine resources. We argue that the palaeoenvironmental 512 conditions, and more specifically the climate, could have played an important role in the 513 observed change in food preferences. However, based on the evidence available, it is 514 not possible to distinguish the effects of climate deterioration in NW Spain at the time 515 from the changes likely brought about by the arrival of new people, the Sueves, who 516 brought a new political and socioeconomic system with them. Understanding how the 517 establishment of Suevic rule in the area may have influenced the subsistence base and in 518 particular the reliance of marine resources and the cultivation of millet is still an open 519 question which will be addressed by further studies. 
This project is the first stable isotope study of a Roman/post-Roman community

521 in the Iberian Peninsula (some isolated skeletons have been reported) and the largest on

522 the Southwestern fringe of the Roman Empire. For future palaeodietary studies, we 523 believe that well-defined local palaeoenvironmental reconstruction can be a highly 524 successful way to examine the causes of dietary change and to distinguish between 525 environmental factors and changes in cultural or economic preferences. This seems 526 particularly important in transitional periods such as after the end of the Roman Empire, 527 where profound environmental changes were coupled with significant political, social 528 and economic change, including migration. We consider that additional investigations 529 are necessary to understand the dietary adaptations in neighbouring areas and periods 530 will provide further insights into these transitions.

\section{ACKNOWLEDGEMENTS}

OLC is funded by Plan Galego I2C mod.A. The research was funded by projects

533 "Antropoloxía dos restos óseos humanos de Galicia” (Dirección Xeral de Patrimonio 534 Histórico), GPC2014/009 and R2014/001 of Xunta de Galicia. Many thanks to the 535 Museo Provincial de Pontevedra and Museo Provincial de Ourense for providing access 536 to the skeletal collections. Advice given by Miguel Botella has been a great help in 537 classifying skeletal features. An especial mention goes to Jose M. Rey Salgado and 538 Aleks Pluskowski for their help with the animal species identification, and to Eduardo 539 González and Víctor Bejega for the information about the fish strategies. Thanks to 540 Milton Núñez, Chus Casais, Antonio Martínez Cortizas, Francisco Fariña, Rafa 541 Rodríguez Martínez, David Varela, Antonio de la Peña, David Fernández Abella and 542 Ángel Costas for their ideas and advices to this study. We thank Tim Mighall for 543 reviewing and commenting a previous version of this manuscript. 
Aira Rodríguez MJ, Ramil Rego P, and Alvarez Núñez A. 1990. Estudio paleocarpológico realizado en el Castro de Penalba (Campolameiro, Pontevedra. España). BotComplut 16:81-89.

Alexander MM, Gerrard CM, Gutiérrez A, and Millard AR. 2015. Diet, society, and economy in late medieval Spain: Stable isotope evidence from Muslims and Christians from Gandía, Valencia. Am. J. Phys. Anthropol. 156(2):263-273.

Arias P, and Schulting RJ. 2010. Análisis de isótopos estables sobre los restos humanos de la BrañaArintero. Aproximación a la dieta de los grupos mesolíticos de la Cordillera Cantábrica. In: Vidal J, and Prada ME, editors. Los hombres mesolíticos de la cueva de La Braña-Arintero (Valdelugueros, León). Valladolid: Junta de Castilla y León. Estudios y Catálogos. p 130-137.

Armas Castro J. 1992. Pontevedra en los siglos XIII a XV, configuración y desarrollo de una villa marinera en la Galicia Medieval. Pontevedra: Fundación Pedro Barrié de la Maza Conde de Fenosa.

Balasse M, and Tresset A. 2002. Early weaning of Neolithic domestic cattle (Bercy, France) revealed by intra-tooth variation in nitrogen isotope ratios. J. Archaeol. Sci. 29(8):853-859.

Balasse M, Tresset A, and Ambrose SH. 2006. Stable isotope evidence (delta C-13, delta O-18) for winter feeding on seaweed by Neolithic sheep of Scotland. J. Zool.270(1):170-176.

Barrett J, Johnstone C, Harland J, Van Neer W, Ervynck A, Makowiecki D, Heinrich D, Hufthammer AK, Enghoff IB, Amundsen C et al. . 2008. Detecting the medieval cod trade: a new method and first results. J. Archaeol. Sci. 35(4):850-861.

Blanco Freijeiro A, Fusté Ara ME, and García Alen A. 1961. La necrópolis galaico-romana de La Lanzada (Noalla, Pontevedra), I. Cuad Estud Gallegos 16:141-158.

Blanco Freijeiro A, Fusté Ara ME, and García Alen A. 1967. La necrópolis galaico-romana de La Lanzada (Noalla, Pontevedra), II. Cuad Estud Gallegos 22:5-23, 129-155.

Britton K, Muldner G, and Bell M. 2008. Stable isotope evidence for salt-marsh grazing in the Bronze Age Severn Estuary, UK: implications for palaeodietary analysis at coastal sites. J. Archaeol. Sci. 35(8):2111-2118.

Büntgen U, Tegel W, Nicolussi K, McCormick M, Frank D, Trouet V, Kaplan JO, Herzig F, Heussner KU, Wanner $\mathrm{H}$ et al. . 2011. 2500 years of European climate variability and human susceptibility. Science 331(6017):578-582.

Campos Ruíz J, and Roca Melia I. 1971. San Leandro, San Isidoro, San Fructuoso, Reglas monásticas de la España visigoda, Los tres libros de las "Sentencias",. Madrid: Biblioteca de Autores Cristianos. Santos Padres Españoles 2.

Carro Otero J, Masa Vázquez MC, and Varela Ogando ML. 1987. Un nuevo enterramiento de la necrópolis galaico-romana de La Lanzada (Noalla-Pontevedra). Pontevedra Arqueológica 2:229252.

Castellanos S, and Viso IM. 2005. The local articulation of central power in the north of the Iberian Peninsula (500-1000). Early Medieval Europe 13(1):1-42.

Cloern JE, Canuel EA, and Harris D. 2002. Stable carbon and nitrogen isotope composition of aquatic and terrestrial plants of the San Francisco Bay estuarine system. Limnol. Oceanogr. 47(3):713729.

Collins MJ, and Galley P. 1998. Towards an optimal method of archaeological collagen extraction: the influence of $\mathrm{pH}$ and grinding. Anc. Biomol. 2:209-222.

Craig OE, Biazzo M, O'Connell TC, Garnsey P, Martínez-Labarga C, Lelli R, Salvadei L, Tartaglia G, Nava A, Reno L et al. . 2009. Stable Isotopic Evidence for Diet at the Imperial Roman Coastal Site of Velia (1st and 2nd Centuries AD) in Southern Italy. Am. J. Phys. Anthropol. 139(4):572583.

Davis M. 2002. Putting meat on the bone: an investigation into palaeodiet in the Balearic Islands using carbon and nitrogen stable isotope analysis. In: Waldren W, and Ensenyat J, editors. World islands in prehistory: international insular investigations V Deià International Conference of Prehistory. Oxford: BAR International Series 1095. p 198-216.

Díaz PC. 2011. El reino suevo (411-585). Tres Cantos, Madrid: Akal, D L.

Dopazo Martínez A, Fernández Rodríguez C, and Ramil Rego P. 1996. Arqueometría aplicada a yacimientos galaico-romanos del NW peninsular, valoración de la actividad agrícola y ganadera. In: Ramil Rego P, Fernández Rodríguez $\mathrm{C}$, and Rodríguez Guitián $\mathrm{M}$, editors. Biogeografía pleistocena -holocena de la Península Ibérica. Santiago de Compostela: Consellería de Cultura. p 317-332. 
Fariña Busto F. 1975. Excavación de A Lanzada (Sanxenxo-Pontevedra); Informe preliminar de la campaña. Museo de Pontevedra 29:165-173.

Fariña Busto F, and Filgueira Valverde JE. 1974. Plan Nacional de Excavaciones 1973: A Lanzada (Sanjenjo, Pontevedra). Museo de Pontevedra 28:83-86.

Fariña Busto F, and Suarez Otero J. 1997. As necrópoles xermano-suévicas. In: García Iglesias XM, editor. Galicia Castrexa e Romana. Lugo: Consellería de Cultura e Comunicación Social.

Ferreiro A. 2008. De prohibitione carnis. Meat Abstention and the Priscillianists. Zeitschrift für Antikes Christentum 11(3):464-478.

Ferreiro García IA, Acuña Castroviejo R, and Durán Neira C. 1993. As Algas en Galicia : alimentación e outros usos: Dirección Xeral de Marisqueo e Acuicultura, D.L Galicia.

Ferro-Vázquez C, Martínez-Cortizas A, Nóvoa-Muñoz JC, Ballesteros-Arias P, and Criado-Boado F. 2014. 1500 years of soil use reconstructed from the chemical properties of a terraced soil sequence. Quat Int (346):28-40.

Filgueira Valverde JE, and Blanco Freijeiro A. 1962. Excavaciones de La Lanzada. Noticiario Arqueológico Hispánico V (1956-1961):137-152.

Fraser RA, Bogaard A, Heaton T, Charles M, Jones G, Christensen BT, Halstead P, Merbach I, Poulton PR, Sparkes D et al. . 2011. Manuring and stable nitrogen isotope ratios in cereals and pulses: towards a new archaeobotanical approach to the inference of land use and dietary practices. J. Archaeol. Sci. 38(10):2790-2804.

Fuertes Prieto MN, and Fernández Rodríguez C. 2010. El comercio y consumo de moluscos en época romana en Asturica Augusta (León). Férvedes 6:147-158.

Fuller B, Marquez-Grant N, and Richards MP. 2010. Investigation of Diachronic Dietary Patterns on the Islands of Ibiza and Formentera, Spain: Evidence from Carbon and Nitrogen Stable Isotope Ratio Analysis. Am. J. Phys. Anthropol. 143(4):512-522.

Fuller BT, Molleson TI, Harris DA, Gilmour LT, and Hedges REM. 2006. Isotopic evidence for breastfeeding and possible adult dietary differences from Late/Sub-Roman Britain. Am. J. Phys. Anthropol.129(1):45-54.

García-Guixé E, Martínez-Moreno J, Mora R, Nunez M, and Richards MP. 2009. Stable isotope analysis of human and animal remains from the Late Upper Palaeolithic site of Balma Guilanya, southeastern Pre-Pyrenees, Spain. J. Archaeol. Sci. 36(4):1018-1026.

García E, Subirà ME, and Richards MP. 2004. Régime et société d'aprés l'analyse des isotopes stable: l'exemple de la population de "Can Reinés" (Mallorca, Espagne, 600 ap. J.C.). Anthropo 7:171176.

García Guixé E, Richards MP, and Subira ME. 2006. Palaeodiets of humans and fauna at the Spanish Mesolithic site of El Collado. Curr. Anthropol. 47(3):549-556.

González Gómez de Agüero E. 2013. La ictiofauna de los yacimientos arqueológicos del noroeste de la Península Ibérica. Doctoral thesis. León: University of León. 474 p.

González Ruibal A. 2004. Facing two seas: Mediterranean and Atlantic contacts in the North-West of Iberia in the first millenium BC. Oxford Journal of Archaeology 23(3):287-317.

Hakenbeck S, McManus E, Geisler H, Grupe G, and O'Connell TC. 2010. Diet and Mobility in Early Medieval Bavaria: A Study of Carbon and Nitrogen Stable Isotopes. Am. J. Phys. Anthropol.143(2):235-249.

Heaton THE. 1987. The N-15/N-14 ratios of plants in South-Africa and Namibia- Relationship to climate and coastal saline environments Oecologia 74(2):236-246.

Hedges REM, Clement JG, Thomas CDL, and O'Connell TC. 2007. Collagen turnover in the adult femoral mid-shaft: Modeled from anthropogenic radiocarbon tracer measurements. Am. J. Phys. Anthropol 133(2):808-816

Hunt H, and Jones M. 2008. Pathways across Asia : exploring the history of Panicum and Setaria in the Indian subcontinent. Pragdhara 18:53-68.

James TK, Rahman A, McGill CR, and Trivedi PD. 2011. Biology and survival of broom corn millet (Panicum miliaceum) seed. N. Z. Plant Prot. 64:142-148.

Jim S, Ambrose SH, and Evershed RP. 2004. Stable carbon isotopic evidence for differences in the dietary origin of bone cholesterol, collagen and apatite: implications for their use in palaeodietary reconstruction. Geochim Cosmochim Acta 68(1):61-72.

Kaal J, López-Costas O, and Martínez Cortizas A. 2016. Diagenetic effects on pyrolysis fingerprints of extracted collagen in archaeological human bones from NW Spain, as determined by pyrolysisGC-MS. J. Archaeol. Sci. 65:1-10.

Kulikowski M. 2004. Late Roman Spain and its Cities. Baltimore: The Johns Hopkins University Press. 
Kylander ME, Weiss DJ, Martínez Cortizas A, Spiro B, García-Sanchez R, and Coles BJ. 2005. Refining the pre-industrial atmospheric $\mathrm{Pb}$ isotope evolution curve in Europe using an 8000 year old peat core from NW Spain. Earth Planet. Sci. Lett.240(2):467-485.

Lebreiro SM, Frances G, Abrantes FFG, Diz P, Bartels-Jonsdottir HB, Stroynowski ZN, Gil IM, Pena LD, Rodrigues T, Jones PD et al. . 2006. Climate change and coastal hydrographic response along the Atlantic Iberian margin (Tagus Prodelta and Muros Ria) during the last two millennia. Holocene 16(7):1003-1015.

Lightfoot E, Šlaus M, and O'Connell TC. 2012. Changing cultures, changing cuisines: Cultural transitions and dietary change in iron age, roman, and early medieval croatia. Am. J. Phys. Anthropol. 148(4):543-556.

Longin R. 1971. New method of collagen extraction for radiocarbon dating. Nature 230(5291):241-242.

López-Costas O. 2015. Taphonomy and burial context of the Roman/post-Roman funerary areas ( $2^{\text {nd }}$ to $6^{\text {th }}$ centuries AD) of A Lanzada, NW Spain. Estudos do Quaternário, APEQ 12:55-67.

López-Costas O. 2012. Antropología de los restos óseos humanos de Galicia: estudio de la población romano y medieval gallega. Doctoral thesis. Granada: University of Granada. $555 \mathrm{p}$.

López-Costas O, Lantes-Suárez O, and Martínez Cortizas A. 2016. Chemical compositional changes in archaeological human bones due to diagenesis: type of bone vs soil environment. J. Archaeol. Sci. in press.

López-Costas O, Müldner G, and Martínez Cortizas A. 2015. Diet and lifestyle in Bronze Age Northwest Spain: the collective burial of Cova do Santo. J. Archaeol. Sci. 55(0):209-218.

Martínez-Cortizas A, Pontevedra-Pombal X, García-Rodeja E, Novoa-Munoz JC, and Shotyk W. 1999. Mercury in a Spanish peat bog: Archive of climate change and atmospheric metal deposition. Science 284(5416):939-942.

Martínez Cortizas A, Mighall T, Pontevedra Pombal X, Novóa Munoz JC, Peiteado Varela E, and Piñeiro Rebolo R. 2005. Linking changes in atmospheric dust deposition, vegetation change and human activities in northwest Spain during the last 5300 years. Holocene 15(5):698-706.

Mighall TM, Martínez Cortizas A, Biester H, and Turner SE. 2006. Proxy climate and vegetation changes during the last five millennia in NW Iberia: Pollen and non-pollen palynomorph data from two ombrotrophic peat bogs in the North Western Iberian Peninsula. Rev. Palaeobot. Palynol. 141(12):203-223.

Mintz SW, and Du Bois CM. 2002. The anthropology of food and eating. Annu Rev Anthropol 31:99119.

Müldner G, and Richards MP. 2007. Diet and diversity at later medieval fishergate: The isotopic evidence. Am. J. Phys. Anthropol.134:162-174.

Mundee M. 2009. An isotopic approach to diet in Medieval Spain. In: Baker S, Allen M, Middle S, and Poole K, editors. Food and Drink in Archaeology 2: University of Nottingham Conference 2009: Prospect, Totnes.

Muñoz Sobrino C, García-Moreiras I, Castro Y, Martínez Carreño N, de Blas E, Fernandez Rodríguez C, Judd A, and García-Gil S. 2014. Climate and anthropogenic factors influencing an estuarine ecosystem from NW Iberia: new high resolution multiproxy analyses from San Simón Bay (Ría de Vigo). Quat Sci Rev 93(0):11-33.

Musset L. 1975. The Germanic invasions : The making of Europe Ad 400-600. London: Elek.

Naveiro López J. 1991. El comercio antiguo en el NW Peninsular. Lectura Histórica del Registro Arqueológico. Sada: do Castro.

O'Connell TC, Kneale CJ, Tasevska N, and Kuhnle GGC. 2012. The diet-body offset in human nitrogen isotopic values: A controlled dietary study. Am. J. Phys. Anthropol149(3):426-434.

Pérez García JM. 1979. Un Modelo de sociedad rural de antiguo régimen en la Galicia costera : la península del Salnés : (Jurisdicción de La Lanzada). Santiago de Compostela: Universidade de Santiago de Compostela. $416 \mathrm{p}$.

Pestle WJ, Crowley BE, and Weirauch MT. 2014. Quantifying Inter-Laboratory Variability in Stable Isotope Analysis of Ancient Skeletal Remains. PLoS ONE 9(7):e102844.

Philpott R. 1991. Burial Practices in Roman Britain. A Survey of Grave Treatment and Furnishing AD 43-410. Oxford: Tempus Reparatum.

Ramil-Rego P. 1993. Paleoethnobotánica de yacimientos arqueológicos holocenos de Galicia (N.O. Cantábrico). Munibe 45:165-174.

Ramil-Rego P, Munoz-Sobrino C, Rodriguez-Guitian M, and Gomez-Orellana L. 1998. Differences in the vegetation of the North Iberian Peninsula during the last 16,000 years. Plant Ecol 138(1):41-62.

Reitsema LJ, Crews DE, and Polcyn M. 2010. Preliminary evidence for medieval Polish diet from carbon and nitrogen stable isotopes. J. Archaeol. Sci. 37(7):1413-1423. 
Richards MP, and Hedges REM. 1999. Stable isotope evidence for similarities in the types of marine foods used by late mesolithic humans at sites along the Atlantic coast of Europe. J. Archaeol. Sci. 26(6):717-722.

Rodríguez Martínez RM, Aboal Fernandez R, Castro Hierro V, Candela Cereijo C, and Ayán Vila JM. 2011. Una posible factoría prerromana en el noroeste. Primeras valoraciones de la intervención en el Campo de A Lanzada (Sanxenxo, Pontevedra). Férvedes 7:159-168.

Rösch M. 1998. The history of crops and crop weeds in south-western Germany from the Neolithic period to modern times, as shown by archaeobotanical evidence. Veg Hist Archaeobot 7(2):109-125.

Sage R, and Monson R, editors. 1999. C4 plant biology. San Diego: CA: Academic Press.

Salazar-García DC, Aura JE, Olària CR, Talamo S, Morales JV, and Richards MP. 2014. Isotope evidence for the use of marine resources in the Eastern Iberian Mesolithic. J. Archaeol. Sci. 42(0):231-240.

Schoeninger M, DeNiro M, and Tauber H. 1983. Stable nitrogen isotope ratios of bone collagen reflect marine and terrestrial components of prehistoric human diet. Science 220:1381-1383.

Schwarcz HP, and Schoeninger MJ. 1991. Stable isotope analyses in human nutritional ecology. Yearb. Phys. Anthropol. 34:283-321.

Sealy J. 2001. Body tissue chemistry and Palaeodiet. In: Brothwell DR, and Pollard AM, editors. Handbook of Archaeological Sciences. Chichester: John Wiley and Sons. p 269-279.

Seijas Montero M. 2001. Los prioratos de San Martín Pinario en el Sudoeste gallego: dominio territorial y situación económica a fines del Antiguo Régimen. Obradoiro Hist Mod 10:121-140.

Spurr MS. 1986. Arable Cultivation in Roman Italy, 200 B.C.- A.D.100. London: Society for the Promotion of Roman Studies. J Roman Stud. Monographs, 3.

Stevens RE, Lightfoot E, Hamilton J, Cunliffe B, and Hedges REM. 2010. Stable isotope investigations of the Danebury. Oxford Journal of Archaeology 29(4):407-428.

Suarez Otero J, and Fariña Busto F. 1990. A Lanzada (Sanxenxo, Pontevedra), definición e interpretación de un yacimiento castreño atípico. Apuntes para un estudio de los intercambios protohistóricos en la costa atlántica peninsular. Madrider Mitteilungen 31:309-337.

Syme R. 1934. The Spanish War of Augustus (26-25 BC). The American Journal of Philology 55:193317.

Tafuri MA, Craig OE, and Canci A. 2009. Stable Isotope Evidence for the Consumption of Millet and Other Plants in Bronze Age Italy. Am. J. Phys. Anthropol.139(2):146-153.

Tereso JP. 2012. Environmental Change, agricultural development and social trends in NW Iberia from the Late Prehistory to the Late Antiquity. Porto: Facultade de Ciencias do Porto. PhD thesis.

Toynbee JM. 1971. Death and burial in the Roman World. London: Thames and Hudson.

Valdés-Bermejo E, and Silva Pando J. 1986. Vegetación del istmo de la Lanzada. Pontevedra: Diputación Provincial, Departamento de Cultura.

Van Groenigen J-W, and van Kessel C. 2002. Salinity-induced Patterns of Natural Abundance Carbon-13 and Nitrogen-15 in Plant and Soil. Soil Sci Soc Am J 66(2):489-498.

Van Strydonck M, Boudini M, and Ervynck A. 2002. Stable isotopes (13C and 15N) and diet: animal and human bone collagen from prehistoric sites in Mallorca, Menorca and Formenter (Balearic Islands, Spain). In: Waldren W, and Ensenyat J, editors. World islands in prehistory: international insular investigations V Deià International Conference of Prehistory. Oxford: BAR International Series. p 189-197.

Van Strydonck M, Boudini M, and Ervynck A. 2005. Spatial and temporal variation of dietary habits during the prehistory of the Balearic Islands as reflected by $14 \mathrm{C}, \mathrm{d} 15 \mathrm{~N}$ and $\mathrm{d} 13 \mathrm{C}$ analyses on human and animal bones. Mayurga 30:523-541.

Vázquez Varela JM, and García Quintela MV. 1998. A vida cotiá na Galicia castrexa. Santiago de Compostela: Biblioteca de divulgación.

Villares R, Carral E, Lorenzana F, and Mosquera EL. 2007. Drift-seaweed evaluation for fertilizer use in galiza (Northwest spain): Tissue elemental characterization and site-sampling differences. J Sustain Agric 31(1):45-60.

Virginia RA, and Delwiche CC. 1982. Natural N-15 abundance of presumed N2-fixing and non N2-fixing plants from selected ecosystems. Oecologia 54(3):317-325. 


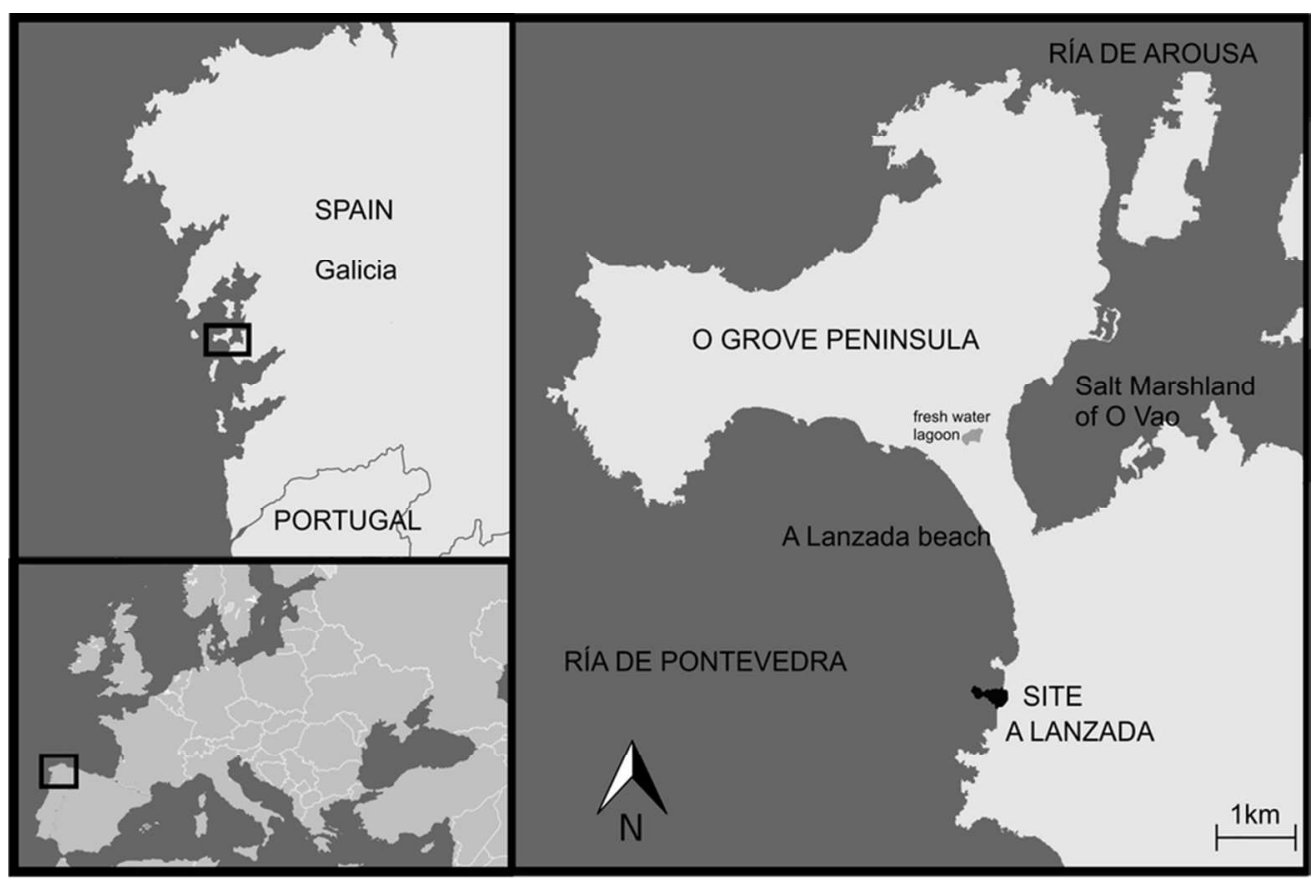

Figure 1. Map of the site location including the main fresh water and marine resources near the site. $78 \times 52 \mathrm{~mm}(300 \times 300 \mathrm{DPI})$ 


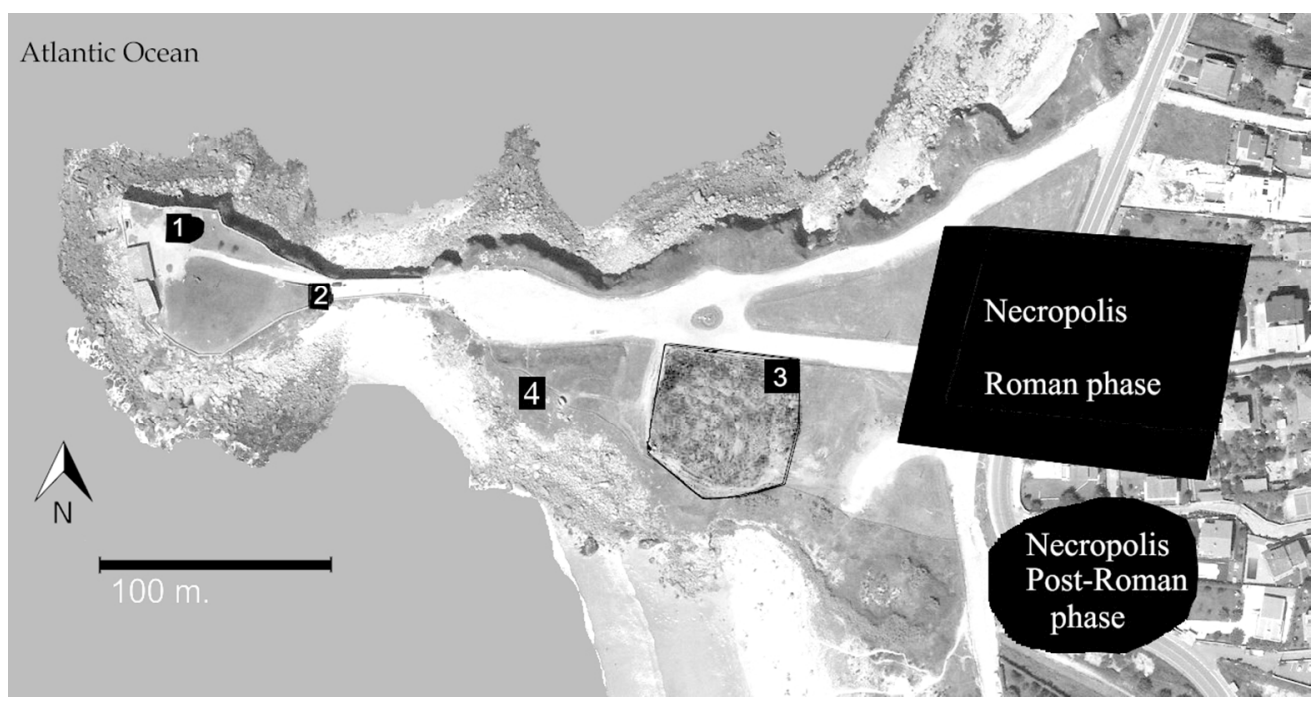

Figure 2.Area of the site at present. The two phases of the necropolis and other archaeological sectors are emphasized, such as the Romanesque church (1), the medieval tower (2) and the Iron Age-Roman settlement area with the seafood salting installation (3). Number 4 indicates where the medieval skeleton was found. Modified from Google Earth @ 2014 Google $338 \times 177 \mathrm{~mm}(96 \times 96 \mathrm{DPI})$ 
Figure 3.Pictures from two representative burials of the Roman (A) and post-Roman(B) phases of $A$ Lanzada necropolis. The picture " $A$ " corresponds to the earth grave of skeleton 202, which contained an imbrex placed under the head, ceramic vessels as gravegoods and hobnails (remains of nailed shoes). The picture "B" shows the stone slab tomb of skeleton 249. A second individual can be seen at the feet of 249, possibly representing and older burial that was moved aside (multiple no-consecutive burial). $63 \times 34 \mathrm{~mm}(300 \times 300 \mathrm{DPI})$ 
Figure 4.Animals bone collagen isotope results. Terrestrial samples are grouped by bone or tooth (dentin). $295 \times 176 \mathrm{~mm}(96 \times 96 \mathrm{DPI})$

John Wiley \& Sons, Inc. 
1

2

3

4

5

6

7

8

9

10

11

12

13

14

15

16

17

18

19

20

21

22

23

24

25

26

27

28

29

30

31

32

33

34

35

36

37

38

39

40

41

42

43

44

45

46

47

48

49

50

51

52

53

54

55

56

57

58

59

60

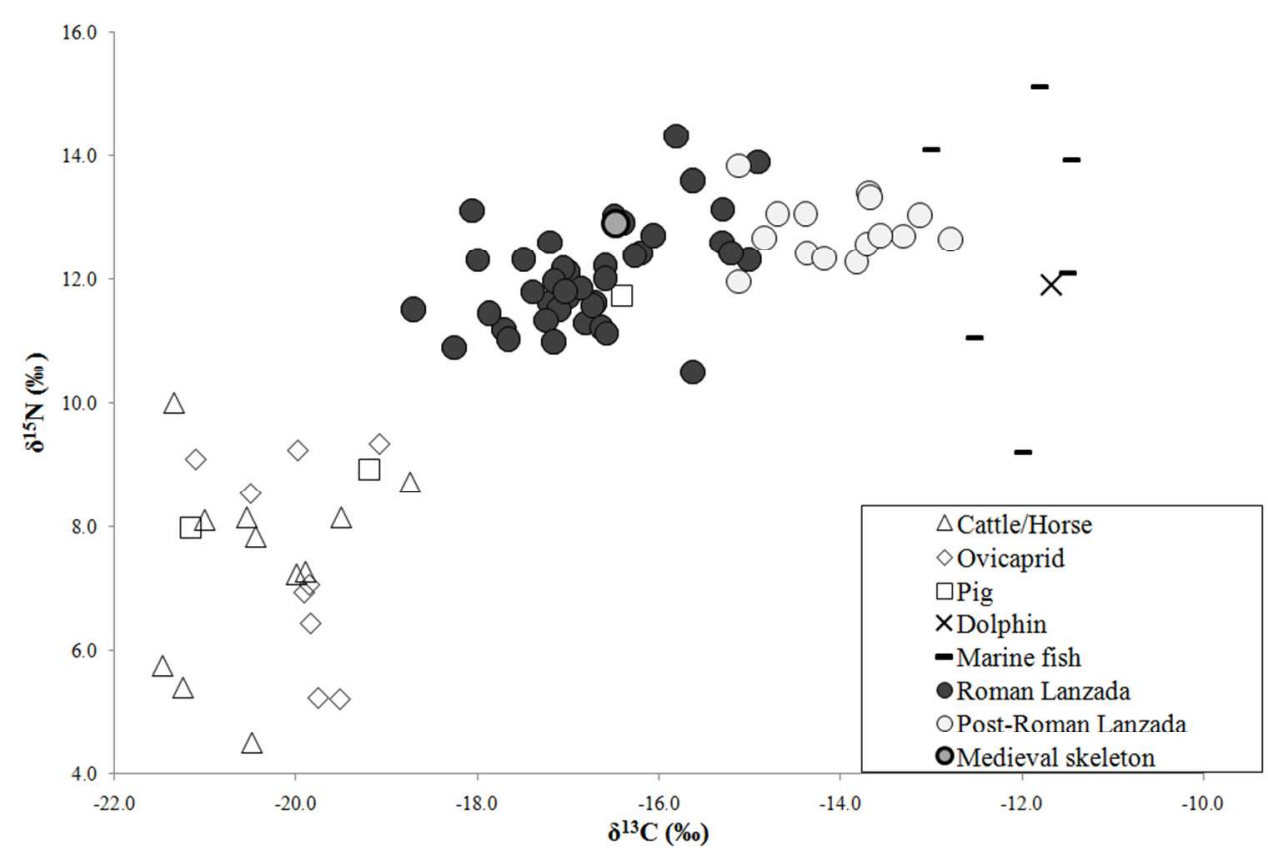

Fig. 5.Bone collagen $\delta 13 \mathrm{C}$ and $\delta 15 \mathrm{~N}$ values of animal and human samples from A Lanzada grouped by time period.

$270 \times 174 \mathrm{~mm}(96 \times 96 \mathrm{DPI})$

John Wiley \& Sons, Inc. 


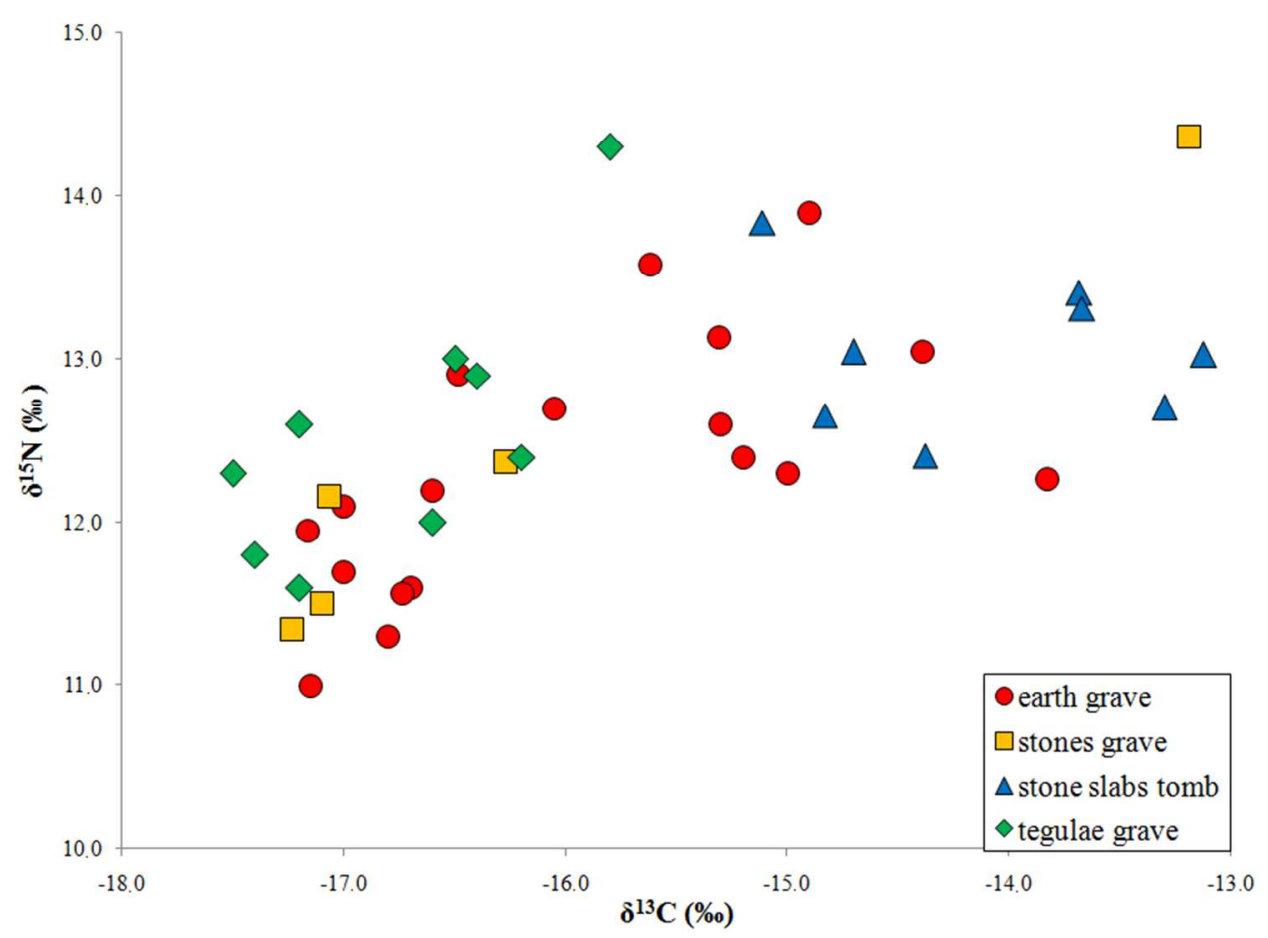

Figure 6. Scatter plot of carbon and nitrogen isotope ratios for humans according to grave typology. Since the information about the burial typology of some skeletons was lost or not totally clear, the sample plot here is smaller than the represented according to the period of use. $240 \times 170 \mathrm{~mm}(96 \times 96 \mathrm{DPI})$ 


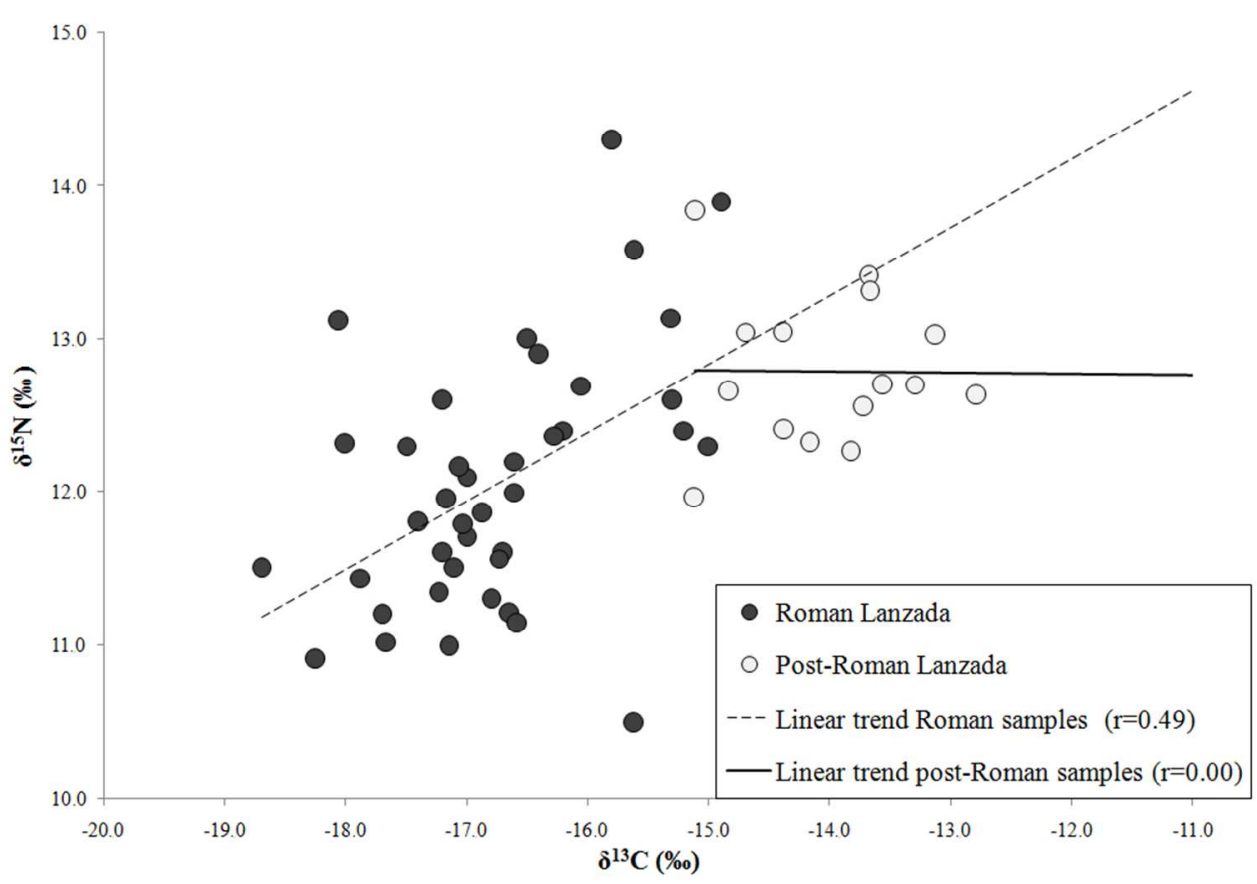

Figure 7. Scatter plot and linear regression of carbon and nitrogen isotope ratios for Roman and post-Roman humans $268 \times 178 \mathrm{~mm}(96 \times 96 \mathrm{DPI})$

John Wiley \& Sons, Inc. 
TABLE 1. Carbon and nitrogen stable isotope ratios, collagen quality indicators, and tentatively species identification of the non human animals.

\begin{tabular}{|c|c|c|c|c|c|c|c|c|c|c|}
\hline Sample number & Site & Animal group & Specie & $\begin{array}{c}\text { Sample } \\
\text { area }\end{array}$ & $\delta 13 \mathrm{C}$ & $\delta 15 \mathrm{~N}$ & $\mathrm{C} / \mathrm{N}$ & $\% \mathrm{C}$ & $\% \mathrm{~N}$ & $\%$ Coll \\
\hline 904 & A Lanzada & Herbivore & Cattle & horn & -18.8 & 8.7 & 3.2 & 35.5 & 12.8 & 11.3 \\
\hline $907 \mathrm{a}$ & “ & “ & Cattle & calcaneus & -20.5 & 4.5 & 3.3 & 33.7 & 11.9 & 6.6 \\
\hline $907 d$ & “ & “ & Cattle & rib & -20.4 & 7.8 & 3.3 & 36.9 & 13.2 & 10.5 \\
\hline $907 f$ & “ & “ & Cattle & metapodial & -20.0 & 7.2 & 3.3 & 28.8 & 10.3 & 4.1 \\
\hline 911 & “ & “ & Cattle & tooth & -19.5 & 8.1 & 3.3 & 41.7 & 14.8 & 7.9 \\
\hline $913 a$ & “ & “ & Cattle & tooth & -20.5 & 8.1 & 3.3 & 42.7 & 15.0 & 10.2 \\
\hline $913 \mathrm{~d}$ & “ & “ & Cattle & talus & -21.5 & 5.8 & 3.4 & 40.3 & 13.7 & 3.1 \\
\hline $914 \mathrm{a}$ & “ & “ & Cattle & tibia & -21.2 & 5.4 & 3.3 & 42.3 & 15.1 & 5.1 \\
\hline $914 b$ & “ & “ & Cattle & radio & -21.0 & 8.1 & 3.3 & 35.9 & 12.8 & 8.2 \\
\hline $906 \mathrm{c}$ & “ & “ & Cattle/horse & tooth & -19.9 & 7.3 & 3.3 & 41.7 & 14.9 & 10.5 \\
\hline $907 \mathrm{e}$ & “ & “ & Cattle/horse & humerus & -21.3 & 10.0 & 3.5 & 25.3 & 8.5 & 5.9 \\
\hline 903 & “ & “ & Ovicaprid & tibia & -19.5 & 5.2 & 3.4 & 29.2 & 10.1 & 5.4 \\
\hline 905 & “ & “ & Ovicaprid & metapodial & -19.1 & 9.3 & 3.2 & 33.7 & 12.2 & 6.9 \\
\hline $906 a$ & “ & “ & Ovicaprid & femur & -17.7 & 11.2 & 3.5 & 22.4 & 7.5 & 5.1 \\
\hline $906 \mathrm{~d}$ & “ & “ & Ovicaprid & cranium & -19.9 & 6.9 & 3.3 & 43.5 & 15.4 & 2.8 \\
\hline $907 \mathrm{~b}$ & “ & “ & Ovicaprid & cranium & -19.8 & 6.4 & 3.3 & 36.9 & 12.9 & 6.2 \\
\hline 908 & “ & “ & Ovicaprid & metapodial & -20.5 & 8.5 & 3.2 & 36.6 & 13.1 & 10.6 \\
\hline 909 & “ & “ & Ovicaprid & tibia & -19.8 & 5.2 & 3.2 & 41.0 & 14.8 & 15.6 \\
\hline 910 & “ & “ & Ovicaprid & tooth & -20.0 & 9.2 & 3.3 & 41.9 & 15.1 & 5.3 \\
\hline $913 b$ & “ & “ & Ovicaprid & tooth & -19.9 & 7.1 & 3.3 & 27.2 & 9.5 & 11.0 \\
\hline $913 \mathrm{c}$ & “ & “ & Ovicaprid & humerus & -21.1 & 9.1 & 3.4 & 34.5 & 11.8 & 5.1 \\
\hline $906 b$ & “ & Omnivore & Pig & femur & -16.4 & 11.7 & 3.3 & 40.5 & 14.3 & 2.6 \\
\hline $907 \mathrm{c}$ & “ & “ & Pig & tibia & -19.2 & 8.9 & 3.4 & 33.8 & 11.6 & 2.5 \\
\hline 912 & “ & “ & Pig & metapodial & -21.2 & 8.0 & 3.3 & 34.2 & 12.0 & 8.6 \\
\hline 936 & Pontevedra & Marine fish & $\begin{array}{l}\text { John Dory } \\
\text { (Zeus faber) }\end{array}$ & jaw & -12.0 & 9.2 & 3.2 & 43.3 & 15.9 & 19.9 \\
\hline 937 & “ & “ & Hake & jaw & -11.8 & 15.1 & 3.1 & 38.8 & 14.6 & 15.8 \\
\hline 938 & $“$ & $“$ & Hake & jaw & -13.0 & 14.1 & 3.2 & 41.3 & 15.0 & 13.5 \\
\hline 939 & “ & “ & $\begin{array}{c}\text { Red porgy } \\
\text { (?Pagruspagrus) }\end{array}$ & jaw & -11.5 & 13.9 & 3.1 & 42.9 & 16.1 & 16.3 \\
\hline 940 & “ & “ & Tuna/Bonito & vertebra & -12.5 & 11.1 & 3.2 & 43.2 & 15.8 & 19.4 \\
\hline 941 & “ & “ & Tuna/Bonito & vertebra & -11.5 & 12.1 & 3.2 & 40.0 & 14.7 & 19.2 \\
\hline 942 & “ & Marine mammal & Dolphin & vertebra & -11.7 & 11.9 & 3.2 & 40.5 & 14.6 & 21.6 \\
\hline
\end{tabular}

John Wiley \& Sons, Inc. 
1

2

3

4

5

6

7

8

9

10

11

12

13

14

15

16

17

18

19

20

21

22

23

24

25

26

27

28

29

30

31

32

33

34

35

36

37

38

39

40

41

42

43

44

45

46

47

48

49

50

51

52

53

54

55

56

57

58

59

60

TABLE 2. Statistical summary of the $\delta^{13} \mathrm{C}$ and $\delta^{15} \mathrm{~N}$ results for terrestrial animals from A Lanzada, NW Spain, and marine animals from a site $20 \mathrm{~km}$ away (Pontevedra).

\begin{tabular}{lcccccc}
\hline & Cattle & Cattle/Horse & Sheep/goat & Suid & Marine fish & Dolphin \\
\hline $\mathrm{n}$ & 9 & 2 & 9 & 3 & 6 & 1 \\
$\overline{\mathrm{X}} \pm S D\left(\delta^{13} \mathrm{C} \% \mathrm{o}\right)$ & $-20.4 \pm 0.9$ & $-19.9,-21.3$ & $-19.9 \pm 0.6$ & $-18.9 \pm 2.4$ & $-12.0 \pm 0.6$ & -11.7 \\
$\overline{\mathrm{X}}_{ \pm S} \mathrm{~S}\left(\delta^{15} \mathrm{~N} \% \mathrm{o}\right)$ & $7.1 \pm 1.5$ & $7.3,10.0$ & $7.5 \pm 1.6$ & $9.5 \pm 1.9$ & $12.6 \pm 2.2$ & -11.9 \\
\hline
\end{tabular}

John Wiley \& Sons, Inc. 
TABLE 3.Carbon and nitrogen stable isotope ratios, collagen quality indicators, anthropological and archaeological information for A Lanzada humans.

\begin{tabular}{|c|c|c|c|c|c|c|c|c|c|c|c|c|c|c|}
\hline $\begin{array}{l}\text { Sample } \\
\text { number }\end{array}$ & Period & $\delta^{13} \mathrm{C}$ & $\delta^{15} \mathrm{~N}$ & $\mathrm{C} / \mathrm{N}$ & $\% \mathrm{C}$ & $\% \mathrm{~N}$ & $\%$ Coll & Sex & $\begin{array}{l}\text { Age } \\
\text { group }\end{array}$ & $\begin{array}{c}\text { Sampled } \\
\text { bone }\end{array}$ & Site area & Orientation & $\begin{array}{c}\text { Grave } \\
\text { typology }\end{array}$ & Notes \\
\hline 201 & Roman & -16.7 & 11.6 & 3.4 & 40.4 & 13.8 & 3.0 & $\mathrm{M}$ & MA & jaw & $\mathrm{N}$ area & SW-NE & eg & $\mathrm{H}$ \\
\hline 202 & R. & -17.5 & 12.3 & 3.6 & 26.6 & 8.7 & 4.5 & M & * & jaw & $\mathrm{N}$ area & S-N & $\operatorname{tg}$ & $\mathrm{G} ; \mathrm{H}$ \\
\hline 203 & $\mathrm{R}$. & -16.5 & 13.0 & 3.3 & 40.5 & 14.3 & 2.7 & M & YA & jaw & $\mathrm{N}$ area & S-N & $\operatorname{tg}$ & $\mathrm{G} ; \mathrm{H}$ \\
\hline 204 & $\mathrm{R}$. & -17.2 & 12.6 & 3.3 & 35.8 & 12.5 & 14.6 & $\mathrm{~F}$ & $*$ & jaw & $\mathrm{N}$ area & S-N & $\operatorname{tg}$ & G \\
\hline 205 & R. & -17.2 & 11.6 & 3.2 & 42.9 & 15.4 & 16.5 & $\mathrm{~F}$ & $*$ & jaw & $\mathrm{N}$ area & S-N & $\operatorname{tg}$ & G \\
\hline 206 & R. & -17.0 & 11.7 & 3.3 & 37.7 & 13.3 & 7.3 & $\mathrm{~F}$ & $*$ & jaw & $\mathrm{N}$ area & S-N & eg & G \\
\hline 207 & $\mathrm{R}$. & -14.9 & 13.9 & 3.4 & 26.9 & 9.2 & 6.3 & M & YA & jaw & $\mathrm{N}$ area & S-N & eg & \\
\hline 208 & R. & -17.0 & 12.1 & 3.4 & 42.3 & 14.5 & 3.1 & M & YA & jaw & $\mathrm{N}$ area & $*$ & eg & \\
\hline 209 & $\mathrm{R}$. & -15.8 & 14.3 & 3.3 & 43.1 & 15.3 & 14.4 & $\mathrm{~F}$ & MA & jaw & $\mathrm{N}$ area & S-N & $\operatorname{tg}$ & G \\
\hline 210 & R. & -15.3 & 13.1 & 3.3 & 41.1 & 14.4 & 3.9 & $\mathrm{~F}$ & YA & jaw & $\mathrm{N}$ area & NE-SW & eg & \\
\hline 211 & $\mathrm{R}$. & -16.8 & 11.3 & 3.3 & 23.7 & 8.3 & 3.5 & M & OA & jaw & $\mathrm{N}$ area & S-N & eg & \\
\hline 212 & R. & -18.7 & 11.5 & 3.5 & 29.8 & 9.8 & 4.1 & M & MA & jaw & $*$ & $*$ & $*$ & \\
\hline 213 & R. & -16.2 & 12.4 & 3.2 & 42.3 & 15.4 & 19.7 & M & OA & jaw & $\mathrm{N}$ area & SE-NW & $\operatorname{tg}$ & \\
\hline 214 & R. & -17.7 & 11.2 & 3.3 & 41.9 & 14.6 & 4.7 & $\mathrm{~F}$ & $*$ & fibula & $*$ & $*$ & $*$ & \\
\hline 215 & R. & -17.4 & 11.8 & 3.2 & 38.1 & 13.8 & 21.6 & M & YA & fibula & $\mathrm{N}$ area & SE-NW & $\operatorname{tg}$ & $\mathrm{G} ; \mathrm{H}$ \\
\hline 216 & R. & -16.4 & 12.9 & 3.3 & 38.4 & 13.7 & 12.3 & M & MA & rib & $\mathrm{N}$ area & SE-NW & $\operatorname{tg}$ & $\mathrm{G} ; \mathrm{H}$ \\
\hline 217 & R. & -16.6 & 12.2 & 3.3 & 43.5 & 15.6 & 17.6 & M & MA & occipital b. & $\mathrm{N}$ area & SE-NW & eg & G \\
\hline 218 & $\mathrm{R}$. & -15.3 & 12.6 & 3.5 & 25.0 & 8.2 & 4.8 & $\mathrm{~F}$ & YA & fibula & $\mathrm{N}$ area & SE-NW & eg & $\mathrm{G} ; \mathrm{H}$ \\
\hline 219 & R. & -17.1 & 11.5 & 3.4 & 41.8 & 14.5 & 3.8 & $\mathrm{~F}$ & YA & ulna & $\mathrm{N}$ area & SW-NE & $\mathrm{sg}$ & G \\
\hline 220 & $\mathrm{R}$. & -16.6 & 12.0 & 3.3 & 42.1 & 15.0 & 16.3 & M & $*$ & radius & $\mathrm{N}$ area & SW-NE & $\operatorname{tg}$ & $\mathrm{S}$ \\
\hline 221 & R. & -15.0 & 12.3 & 3.6 & 24.2 & 7.6 & 5.1 & M & YA & fibula & $\mathrm{N}$ area & S-N & eg & \\
\hline 222 & $\mathrm{R}$. & -15.2 & 12.4 & 3.5 & 22.8 & 7.6 & 4.6 & $\mathrm{~F}$ & MA & fibula & $\mathrm{N}$ area & S-N & eg & \\
\hline 223 & R. & -15.6 & 13.6 & 3.6 & 18.9 & 6.1 & 7.4 & $\mathrm{~F}$ & YA & fibula & $\mathrm{N}$ area & S-N & eg & \\
\hline 224 & R. & -13.2 & 14.4 & 3.4 & 33.6 & 11.6 & 9.2 & $\mathrm{~F}$ & YA & fibula & $\mathrm{N}$ area & S-N & $\mathrm{sg}$ & \\
\hline 225 & R. & -17.1 & 12.2 & 3.5 & 19.0 & 6.3 & 4.3 & $\mathrm{M}$ & MA & ulna & $\mathrm{N}$ area & S-N & $\mathrm{sg}$ & G \\
\hline 226 & R. & -16.7 & 11.6 & 3.2 & 40.5 & 14.6 & 19.5 & $\mathrm{~F}$ & MA & radius & $\mathrm{N}$ area & S-N & eg & $\mathrm{G} ; \mathrm{H}$ \\
\hline 227 & R. & -17.2 & 11.3 & 3.2 & 43.1 & 15.7 & 22.8 & $\mathrm{~F}$ & MA & fibula & $\mathrm{N}$ area & S-N & $\mathrm{sg}$ & $\mathrm{G} ; \mathrm{H}$ \\
\hline 228 & R. & -16.3 & 12.4 & 3.4 & 23.8 & 8.2 & 8.1 & $\mathrm{M}$ & MA & radius & $\mathrm{N}$ area & SE-NW & $\mathrm{sg}$ & \\
\hline 229 & R. & -16.1 & 12.7 & 3.3 & 41.1 & 14.6 & 12.2 & $\mathrm{~F}$ & MA & fibula & $\mathrm{N}$ area & S-N & eg & \\
\hline 230 & R. & -17.2 & 11.0 & 3.3 & 34.8 & 12.5 & 12.9 & M & OA & ulna & $\mathrm{N}$ area & S-N & eg & $\mathrm{G} ; \mathrm{H}$ \\
\hline 231 & R. & -18.2 & 10.9 & 3.6 & 31.2 & 10.1 & 4.8 & $\mathrm{M}$ & YA & fibula & $\mathrm{N}$ area & $*$ & $*$ & \\
\hline 232 & R. & -18.0 & 12.3 & 3.4 & 32.8 & 11.2 & 5.6 & $\mathrm{M}$ & MA & fibula & $\mathrm{N}$ area & $*$ & $*$ & \\
\hline 233 & $\mathrm{R}$. & -16.6 & 11.2 & 3.4 & 24.7 & 8.4 & 4.3 & $\mathrm{M}$ & YA & radius & $\mathrm{N}$ area & $*$ & $*$ & \\
\hline 234 & R. & -18.1 & 13.1 & 3.6 & 20.8 & 6.8 & 3.7 & $\mathrm{M}$ & YA & radius & $\mathrm{N}$ area & $*$ & $*$ & \\
\hline 235 & $\mathrm{R}$. & -17.9 & 11.4 & 3.3 & 31.3 & 11.0 & 5.8 & $\mathrm{~F}$ & YA & humerus & $\mathrm{N}$ area & $*$ & $*$ & \\
\hline 236 & $\mathrm{R}$. & -16.9 & 11.9 & 3.5 & 40.6 & 13.7 & 2.7 & $\mathrm{~F}$ & $*$ & humerus & $\mathrm{N}$ area & $*$ & $*$ & \\
\hline 237 & R. & -16.6 & 11.1 & 3.3 & 37.1 & 13.2 & 7.2 & $*$ & SA & ulna & $\mathrm{N}$ area & $*$ & $*$ & \\
\hline 238 & $\mathrm{R}$. & -17.2 & 12.0 & 3.3 & 32.5 & 11.5 & 7.7 & $*$ & SA & tibia & $\mathrm{N}$ area & S-N & eg & G \\
\hline 239 & R. & -15.6 & 10.5 & 3.2 & 44.7 & 16.4 & 22.7 & $*$ & SA & humerus & $\mathrm{N}$ area & $*$ & $*$ & \\
\hline 241 & $\mathrm{R}$. & -17.4 & 12.6 & 3.3 & 42.0 & 15.1 & 19.9 & M & YA & rib & $\mathrm{N}$ area & $*$ & $*$ & \\
\hline 243 & $\mathrm{R}$. & -17.4 & 11.1 & 3.3 & 41.7 & 14.9 & 6.9 & $*$ & SA & phalange & $\mathrm{N}$ area & $*$ & $*$ & \\
\hline 247 & $\mathrm{R}$. & -17.0 & 11.8 & 3.4 & 39.6 & 13.8 & 5.0 & $\mathrm{~F}$ & MA & coxal b. & $\mathrm{S}$ area & $*$ & $*$ & \\
\hline 254 & $\mathrm{R}$. & -17.7 & 11.0 & 3.4 & 28.8 & 10.0 & 6.7 & M & YA & rib & $\mathrm{N}$ area & $*$ & $*$ & \\
\hline
\end{tabular}




\begin{tabular}{|c|c|c|c|c|c|c|c|c|c|c|c|c|c|c|}
\hline $\begin{array}{l}\text { Sample } \\
\text { number }\end{array}$ & Period & $\delta^{13} \mathrm{C}$ & $\delta^{15} \mathrm{~N}$ & $\mathrm{C} / \mathrm{N}$ & $\% \mathrm{C}$ & $\% \mathrm{~N}$ & $\%$ Coll & Sex & $\begin{array}{l}\text { Age } \\
\text { group }\end{array}$ & $\begin{array}{c}\text { Sampled } \\
\text { bone }\end{array}$ & Site area & Orientation & $\begin{array}{c}\text { Grave } \\
\text { typology }\end{array}$ & Notes \\
\hline 240 & Post-Roman & -12.8 & 12.6 & 3.3 & 41.6 & 14.6 & 7.4 & M & YA & rib & $\mathrm{S}$ area & $*$ & $*$ & \\
\hline 242 & P-R & -13.8 & 12.3 & 3.3 & 40.5 & 14.4 & 4.5 & M & YA & rib & $\mathrm{S}$ area & $*$ & eg & \\
\hline 244 & P-R & -14.4 & 12.4 & 3.3 & 35.7 & 12.5 & 7.1 & $\mathrm{~F}$ & YA & rib & $\mathrm{S}$ area & W-E & sts & \\
\hline 246 & P-R & -13.1 & 13.0 & 3.2 & 41.2 & 14.8 & 14.9 & M & MA & rib & $\mathrm{S}$ area & W-E & sts & \\
\hline 248 & P-R & -15.1 & 12.0 & 3.3 & 36.1 & 12.6 & 8.6 & $\mathrm{~F}$ & OA & rib & $\mathrm{S}$ area & $*$ & $*$ & \\
\hline 249 & P-R & -14.8 & 12.7 & 3.4 & 26.1 & 8.8 & 4.3 & M & OA & occipital b. & $\mathrm{S}$ area & W-E & sts & \\
\hline 250 & P-R & -13.7 & 12.6 & 3.4 & 35.7 & 12.2 & 8.5 & $\mathrm{~F}$ & MA & rib & $\mathrm{S}$ area & $*$ & $*$ & \\
\hline 251 & P-R & -13.3 & 12.7 & 3.4 & 29.1 & 10.1 & 6.0 & M & MA & rib & $\mathrm{S}$ area & W-E & sts & \\
\hline 252 & P-R & -14.4 & 13.0 & 3.3 & 32.7 & 11.6 & 6.8 & $\mathrm{~F}$ & YA & rib & $\mathrm{S}$ area & N-S & eg & \\
\hline 253 & P-R & -13.6 & 12.7 & 3.3 & 35.2 & 12.6 & 8.6 & $\mathrm{~F}$ & YA & scapula & $\mathrm{S}$ area & * & $*$ & \\
\hline 255 & P-R & -15.1 & 13.8 & 3.4 & 39.6 & 13.6 & 6.3 & $\mathrm{~F}$ & MA & occipital b. & $\mathrm{S}$ area & W-E & sts & \\
\hline 256 & P-R & -13.7 & 13.4 & 3.3 & 40.5 & 14.2 & 6.4 & $\mathrm{~F}$ & MA & rib & $\mathrm{S}$ area & W-E & sts & \\
\hline 257 & P-R & -14.7 & 13.0 & 3.4 & 27.6 & 9.5 & 5.7 & M & YA & occipital b. & $\mathrm{S}$ area & W-E & sts & \\
\hline 258 & P-R & -13.7 & 13.3 & 3.3 & 31.7 & 11.1 & 6.3 & $*$ & SA & rib & $\mathrm{S}$ area & W-E & sts & \\
\hline 259 & $\mathrm{P}-\mathrm{R}$ & -14.2 & 12.3 & 3.3 & 36.4 & 12.8 & 10.7 & $*$ & SA & scapula & $\mathrm{S}$ area & $*$ & $*$ & \\
\hline 245 & Medieval & -16.5 & 12.9 & 3.6 & 40.3 & 13.1 & 1.6 & M & YA & tibia & $\mathrm{W}$ area & $*$ & eg & \\
\hline
\end{tabular}

Anthropological and archaeological data was extracted from López Costas thesis ( 2012).

* information on burial type is lost or cannot be determined.

Key: $\mathrm{M}=$ male; $\mathrm{F}=$ female. SA Subadult (13-20 years), there were no individuals younger than 12 years old; $\mathrm{YA}=$ young adult (20-35 years); $\mathrm{MA}=$ middle adult ( $35-50$ years); $\mathrm{OA}=$ old adult (50+ years); eg=earth grave; $\mathrm{sg}=$ =stones grave; sts=stone slabs tomb; $\mathrm{tg}=$ =tegulae grave; $\mathrm{G}=$ =with grave goods; $\mathrm{H}=$ hobnails. 
TABLE 4. Statistical summary of the $\delta^{13} \mathrm{C}$ and $\delta^{15} \mathrm{~N}$ results for Roman, Post-Roman and Medieval periods.

\begin{tabular}{lccc}
\hline & Roman period & Post-Roman Period & Medieval \\
\hline $\mathrm{n}$ & 43 & 15 & 1 \\
$\overline{\mathrm{X}} \pm S D(\delta 13 \mathrm{C} \%)$ & $-16.7 \pm 1.0$ & $-14.3 \pm 0.7$ & -16.5 \\
$\overline{\mathrm{X}} \pm S D\left(\delta^{15} \mathrm{~N} \% \mathrm{o}\right)$ & $12.1 \pm 0.9$ & $12.8 \pm 0.5$ & 12.9 \\
\hline
\end{tabular}


1

2

3

4

5

6

7

8

9

10

11

12

13

14

15

16

17

18

19

20

21

22

23

24

25

26

27

28

29

30

31

32

33

34

35

36

37

38

39

40

41

42

43

44

45

46

47

48

49

50

51

52

53

54

55

56

57

58

59

60

TABLE 5. Statistical summary of the human $\delta^{13} \mathrm{C}$ and $\delta^{15} \mathrm{~N}$ according to grave typology

\begin{tabular}{ccccc}
\hline & Tegulae graves & Stone graves & Earth graves & Stone slabs tombs \\
\hline $\mathrm{n}$ & 9 & 5 & 18 & 8 \\
$\overline{\mathrm{X}} \pm \mathrm{SD}(\delta 13 \mathrm{C} \% \mathrm{o})$ & $-16.8 \pm 0.6$ & $-16.2 \pm 1.7$ & $-16.0 \pm 1.0$ & $-14.1 \pm 0.8$ \\
$(\min , \mathrm{Max})$ & $(-17.5,-15.8)$ & $(-17.2,-13.2)$ & $(-17.2,-13.8)$ & $(-15.1,-13.1)$ \\
& & & & $13.0 \pm 0.5$ \\
$\overline{\mathrm{X}} \pm \mathrm{SD}(\delta 15 \mathrm{~N} \% 0)$ & $12.5 \pm 0.8$ & $12.3 \pm 1.2$ & $12.4 \pm 0.8$ & $(12.4,13.8)$ \\
$(\min , \mathrm{Max})$ & $(11.6,14.3)$ & $(11.4,14.4)$ & $(11.0,13.9)$ & \\
\hline
\end{tabular}

John Wiley \& Sons, Inc. 
TABLE 6. Statistical summary and inter-groups comparison analysis of $\delta^{13} \mathrm{C}$ and $\delta^{15} \mathrm{~N}$ arranged by estimated sex in Roman and Post-Roman phases.

\begin{tabular}{|c|c|c|c|}
\hline & Male & Female & M-W-test \\
\hline $\begin{array}{l}\text { A Lanzada Roman } \\
\mathrm{n} \\
\overline{\mathrm{X}} \pm S D(\delta 13 \mathrm{C} \%) \\
\overline{\mathrm{X}} \pm S D\left(\delta^{15} \mathrm{~N} \% \mathrm{o}\right)\end{array}$ & $\begin{array}{c}22 \\
-16.9 \pm 0.9 \\
12.1 \pm 0.8\end{array}$ & $\begin{array}{c}17 \\
-16.4 \pm 1.2 \\
12.3 \pm 1.0\end{array}$ & $\begin{array}{l}\text { U } 230.0 p=0.22 \\
\text { U } 208.5 p=0.54\end{array}$ \\
\hline $\begin{array}{l}\text { A LanzadaPost-Roman } \\
\mathrm{n} \\
\overline{\mathrm{X}} \pm S D(\delta 13 \mathrm{C} \% \mathrm{o}) \\
\overline{\mathrm{X}} \pm S D\left(\delta^{15} \mathrm{~N} \% \mathrm{o}\right)\end{array}$ & $\begin{array}{c}6 \\
-13.8 \pm 0.8 \\
12.7 \pm 0.3\end{array}$ & $\begin{array}{c}7 \\
-14.3 \pm 0.6 \\
12.8 \pm 0.6\end{array}$ & $\begin{array}{l}\text { U } 13.0 p=0.29 \\
\text { U } 22.5 p=0.83\end{array}$ \\
\hline
\end{tabular}

John Wiley \& Sons, Inc. 
2
TABLE 7. Statistical summary and inter-groups comparison analysis of $\delta^{13} \mathrm{C}$ and $\delta 15 \mathrm{~N}$ arranged by estimated age at death in Roman and Post-Roman phases.

\begin{tabular}{lcccc|c}
\hline & $13-20$ years & $20-35$ years & $35-50$ years & $>50$ years & K-W test \\
\hline A Lanzada Roman & & & & & \\
$\mathrm{n}$ & 4 & 16 & 13 & 3 & \\
$\overline{\mathrm{X}} \pm S D(\delta 13 \mathrm{C} \%$ o $)$ & $-16.7 \pm 0.8$ & $-16.4 \pm 1.4$ & $-16.7 \pm 0.9$ & $-16.7 \pm 0.5$ & $\mathrm{H}_{(3)}=0.08, \mathrm{p}=0.99$ \\
$\overline{\mathrm{X}} \pm S D\left(\delta^{15} \mathrm{~N} \% \mathrm{o}\right)$ & $11.2 \pm 0.6$ & $12.4 \pm 1.1$ & $12.2 \pm 0.8$ & $11.6 \pm 0.7$ & $\mathrm{H}_{(3)}=7.06, \mathrm{p}=0.07$ \\
& & & & & \\
A LanzadaPost-Roman & 2 & 6 & 5 & 2 & \\
$\mathrm{n}$ & -14.2 & $-13.9 \pm 0.7$ & $-13.8 \pm 0.8$ & $-14.8 \pm 0.2$ & $\mathrm{H}_{(3)}=4.13, \mathrm{p}=0.25$ \\
$\overline{\mathrm{X}} \pm S D(\delta 13 \mathrm{C} \%)$ & 12.8 & $12.7 \pm 0.3$ & $13.1 \pm 0.5$ & $12.3 \pm 0.5$ & $\mathrm{H}_{(3)}=3.41, \mathrm{p}=0.33$ \\
$\overline{\mathrm{X}} \pm S D\left(\delta^{15} \mathrm{~N} \%\right)$ & & & & &
\end{tabular}

